OPEN ACCESS

Edited by:

Shigeru Saito,

University of Toyama, Japan

Reviewed by:

Sayaka Tsuda

University of Toyama, Japan Lianjun Zhang,

Suzhou Institute of Systems Medicine (ISM), China

*Correspondence: Michael Eikmans m.eikmans@/umc.n

Specialty section This article was submitted to Immunological Tolerance and

Regulation

a section of the journal

Frontiers in Immunology

Received: 30 March 2020 Accepted: 13 May 2020

Published: 23 June 2020

Citation:

Krop J, Heidt S, Claas FHJ and Eikmans M (2020) Regulatory T Cells in Pregnancy: It Is Not All About FoxP3. Front. Immunol. 11:1182. doi: 10.3389/fimmu.2020.01182

\section{Regulatory T Cells in Pregnancy: It Is Not All About FoxP3}

\author{
Juliette Krop, Sebastiaan Heidt, Frans H. J. Claas and Michael Eikmans* \\ Department of Immunohematology and Blood Transfusion, Leiden University Medical Center, Leiden, Netherlands
}

In pregnancy, the semi-allogeneic fetus needs to be tolerated by the mother's immune system. Regulatory $T$ cells (Tregs) play a prominent role in this process. Novel technologies allow for in-depth phenotyping of previously unidentified immune cell subsets, which has resulted in the appreciation of a vast heterogeneity of Treg subsets. Similar to other immunological events, there appears to be great diversity within the Treg population during pregnancy, both at the maternal-fetal interface as in the peripheral blood. Different Treg subsets have distinct phenotypes and various ways of functioning. Furthermore, the frequency of individual Treg subsets varies throughout gestation and is altered in aberrant pregnancies. This suggests that distinct Treg subsets play a role at different time points of gestation and that their role in maintaining healthy pregnancy is crucial, as reflected for instance by their reduced frequency in women with recurrent pregnancy loss. Since pregnancy is essential for the existence of mankind, multiple immune regulatory mechanisms and cell types are likely at play to assure successful pregnancy. Therefore, it is important to understand the complete microenvironment of the decidua, preferably in the context of the whole immune cell repertoire of the pregnant woman. So far, most studies have focused on a single mechanism or cell type, which often is the FoxP3 positive regulatory $T$ cell when studying immune regulation. In this review, we instead focus on the contribution of FoxP3 negative Treg subsets to the decidual microenvironment and their possible role in pregnancy complications. Their phenotype, function, and effect in pregnancy are discussed.

Keywords: regulatory T (Treg) cells, pregnancy, preeclampsia, Tr1 regulatory cells, Th3 regulatory cells, HLA-G Treg, immune tolerance, recurrent pregnancy loss (RPL)

\section{PLACENTAL DEVELOPMENT AND IMMUNE EVASION BY TROPHOBLASTS}

The most striking feature of pregnancy is that a semi-allogeneic fetus is tolerated by the maternal immune system. This is in sharp contrast with solid organ transplantation, where an allograft will be rejected by the patient's immune system unless the patient takes immunosuppressive drugs. Since direct contact between maternal and fetal cells occurs at the maternal-fetal interface in the placenta, it is thought that maternal immune cells in the placenta do not attack the fetal cells (trophoblasts) because of the tolerogenic microenvironment created by regulatory $\mathrm{T}$ cells (Tregs) and other immune cells. 


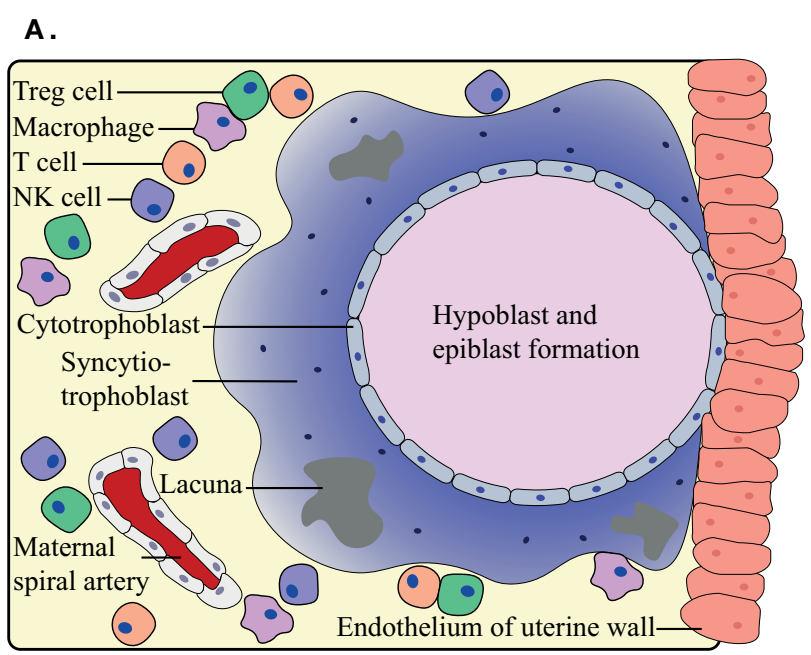

B.

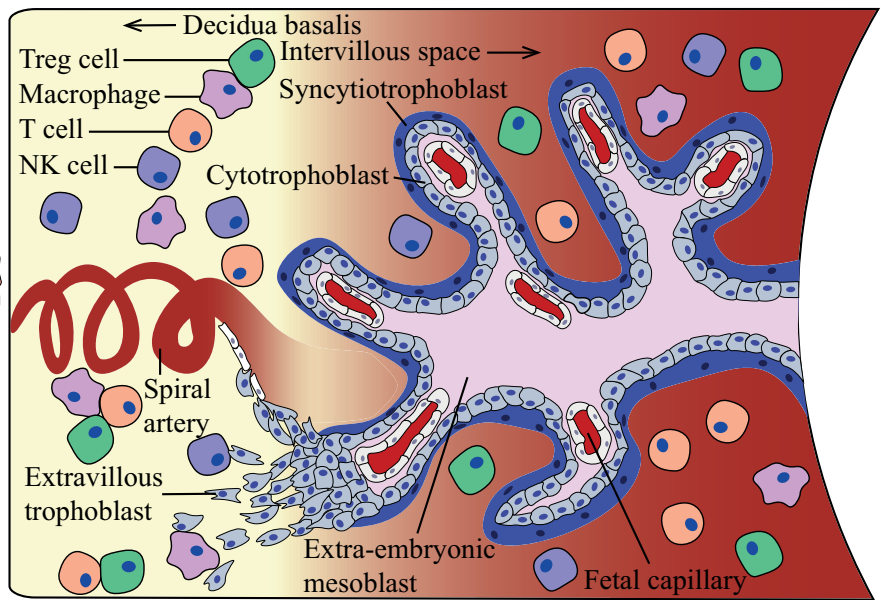

FIGURE 1 | Schematic overview of the maternal-fetal interface at different trimesters. (A) During first-trimester, the maternal immune cells in the decidua can come into contact with fetal syncytiotrophoblasts, when around weeks 11-12 the maternal blood flow commences (B) a second maternal-fetal interface occurs. The maternal immune cells in the periphery can come into contact with fetal syncytiotrophoblasts, while the maternal decidual immune cells are in contact with the fetal extravillous trophoblasts. Indicating immunotolerance needs to adapt during the shift in gestation.

\section{Trophoblast Development}

The main function of the placenta is to provide oxygen and nutrients to the developing fetus. In the first-trimester, nutrients are mainly provided by uterine glands in a hypoxic environment as no active maternal blood flow has been established yet. Once active maternal blood flow in the placenta has commenced around weeks 11-12 of gestation, oxygen and nutrients are exchanged over a thin lining of fetal cells. Since the fetus is semiallogeneic, as it inherits both maternal and paternal antigens, the fetal trophoblast cells may potentially be recognized as foreign by maternal immune cells. Three main types of trophoblasts can be distinguished: cytotrophoblasts (CTBs), syncytiotrophoblasts (SCTs), and extravillous trophoblasts (EVTs). At the beginning of the first trimester, the maternal-fetal interface consists of the maternal parenchymal cells in the decidua and the fetal SCTs (Figure 1A). Later in pregnancy, this interface is mainly represented by maternal decidual cells and the EVTs (Figure 1B), where a distinction is made between decidua basalis and decidua parietalis. Importantly, a second maternal-fetal interface is established when active maternal blood flow in the placenta has commenced. The maternal peripheral blood then comes into contact with the SCTs lining the fetal villi. From the moment these maternal-fetal interfaces have been established, it is of utmost importance for maternal immune cells to keep the balance between tolerizing the semi-allogeneic fetus, and at

Abbreviations: Tregs, regulatory $\mathrm{T}$ cells; tTreg, thymic derived regulatory $\mathrm{T}$ cell; pTreg, periphery induced regulatory T cell; EVTs, cytotrophoblasts (CTBs), syncytiotrophoblasts (SCTs), and extravillous trophoblasts; HLA, human leukocyte antigen; APCs, antigen presenting cells; KIR, killer-cell immunoglobulin-like receptor; TCR, T cell receptor; IDO, indoleamine 2,3-dioxygenase; dNK, decidual NK; RPL, recurrent pregnancy loss; PE, pre-eclampsia; SNPs, single nucleotide polymorphisms; NK, natural killer; ILCs, innate lymphoid cell; DCs, dendritic cells; DC-10, tolerogenic DCs; mTOR, mammalian target of rapamycin; NO, nitric oxide; TGF- $\beta$, transforming growth factor-beta; IFN- $\gamma$, interferon gamma. the same time maintaining the ability to form a robust immune response against pathogens upon infection.

\section{Mechanisms by Trophoblasts for Avoiding and Modulating Immune Responses}

The classical human leukocyte antigen (HLA) class I molecules HLA-A, $-\mathrm{B}$, and -C are normally present on virtually all nucleated cells in the body and present intracellular antigens to surveilling $T$ cells. Non-classical HLA molecules are selectively present, and have initially been described on trophoblasts in the placenta (1) and later also in other tissues (2-4). HLA class II is mainly expressed by antigen-presenting cells (APCs), including dendritic cells (DCs), macrophages, and B cells. Since the fetus inherits half of its genes from the father, it also inherits half of the paternal HLA alleles, which can potentially be recognized as foreign by the maternal immune system.

One way for the trophoblasts to evade recognition by the maternal immune system is lack of the polymorphic HLA-A, $\mathrm{B}$, and HLA class II molecules on their cell surface. Interestingly, EVTs do express polymorphic classical HLA-C molecules. The regular function of these molecules is to present a wide variety of pathogen-associated peptides to surveilling $\mathrm{CD}^{+} \mathrm{T}$ cells (5). Since HLA-C is polymorphic, its presence on trophoblasts can possibly also lead to allorecognition of the inherited paternal HLA-C by maternal T cells (6). EVTs may help to tip the local maternal immune balance toward tolerance by their expression of non-classical HLA-E and HLA-G (7), and possibly also HLA-F (8). The mechanisms responsible for the presence or absence of the specific HLA class I types on trophoblasts have not fully been elucidated yet (5). Expression of HLA molecules on trophoblasts allows them to escape natural killer (NK) cell recognition (9). HLA-G was first described on CTBs and has been shown to induce immune tolerance $(10,11)$ (described below). HLA-E also has tolerogenic properties as it can bind to the NK cell receptor 
CD94/NKG2A upon which NK cell activity is inhibited (12). SCTs, which are in direct contact with the maternal blood, do not express any HLA molecules (13), which would potentially render them sensitive to NK cell-mediated killing (13). However, for NK cells killing an activating ligand needs to be present on the target cell, which is likely missing on trophoblasts (14).

Trophoblasts express several molecules that are thought to dampen alloimmune reactivity, including PD-L1, PD-L2, CD200, and FasL (15-19), some of which are differentially expressed throughout gestation (17). Trophoblasts are also known to produce soluble factors with an immune-modulatory action, such as soluble HLA-G (sHLA-G), transforming growth factorbeta (TGF- $\beta$ ), and indoleamine 2,3-dioxygenase (IDO). TGF- $\beta$ is known to have various functions and will be extensively discussed below. Since IDO causes local tryptophan deprivation (20), which is an essential amino acid required for $\mathrm{T}$ cell activation, elevated local IDO levels lead to inhibition of T cell activation. Recently, the role of galectins in pregnancy has become more apparent, as they were found to play an important role in suppressing the maternal immune system (21). Galectins on human trophoblasts modulate a number of regulatory mechanisms (22), such as induction of $\mathrm{T}$ cell apoptosis (23) and induction of Treg cell development (24).

\section{Maternal Immune Cells in the Decidua}

Not only the composition of fetal cells in the placenta but also the composition of maternal immune cells changes throughout gestation. Already before conception, as early as seminal plasma exposure, activation and proliferation of fetus-specific maternal $\mathrm{T}$ cells in uterine draining lymph nodes have been observed in murine models (25). In humans, maternal APCs and $\mathrm{CD}^{+} \mathrm{T}$ cells seem to get recruited to the ectocervix upon coitus, but their specificity remains unknown (26). In the first trimester of human pregnancy, maternal leukocytes account for 30-40\% of all cells in the decidua (27). During this period, the most prominent immune cells are decidual NK (dNK) cells ( $\sim 60 \%)$, macrophages $(\sim 20 \%)$, and T cells $(\sim 10 \%)(27-29)$. During gestation, dNK cell frequencies decrease, macrophage frequencies remain relatively stable, and T cell frequencies increase (29). Next to these main immune cell populations, innate lymphoid cell (ILCs) other than NK cells, DCs, B cells, NKT cells, granulocytes, and mast cells are found in the decidua (30-32).

Despite the many mechanisms that trophoblasts have to evade an alloimmune response, fetus specific immune recognition has been observed in mice (33). Furthermore, fetus-specific $\mathrm{CD}^{+} \mathrm{T}$ cells $(34,35)$ and inherited paternal antigen (IPA)specific antibodies are found in maternal peripheral blood during pregnancy (36-38). Both HLA-C and HLA-E restricted CD8 ${ }^{+}$ $\mathrm{T}$ cells, specific for viral and bacterial peptides, are present in humans (39). However, maternal $\mathrm{CD}^{+} \mathrm{T}$ cells could recognize the paternally inherited HLA-C from the fetus or fetal minor histocompatibility antigens, and if not suppressed are likely to attack the fetal trophoblasts $(34,35)$. Besides this, $\sim 30 \%$ of pregnancies result in the formation of paternal HLA-specific IgG antibodies $(38,40)$. Allo-antibodies directed against HLA-C of the fetus do not necessarily appear to be detrimental to pregnancy outcome (41), but some studies do show that they are associated with spontaneous preterm deliveries and recurrent pregnancy loss (RPL) $(42,43)$. Therefore, to inhibit the effect of maternal immune components, it is thought that local immune regulation is required to prevent anti-fetal immunity.

\section{MATERNAL TREG CELLS DURING GESTATION}

To prevent a detrimental immune reaction against the fetus, maternal immune cells need to be regulated. The level of both FoxP3 $^{+}$and Foxp $3^{-}$Tregs is increased in the peripheral blood of pregnant women compared to non-pregnant control women $(44,45)$. While the proportion of total $\mathrm{T}$ cells in the decidua is low during the first trimester ( $\sim 10 \%)$, of which $10-30 \%$ of the $\mathrm{CD}^{+}$ T cells are Tregs $(28,29,46,47)$, later in pregnancy the proportion of Tregs significantly increases in the decidua [(46); van der Zwan et al. submitted]. In mice the importance of Tregs during implantation and for maintenance of a healthy pregnancy is evident. This was shown in murine studies by injecting abortion prone mice with $\mathrm{CD} 25^{+}$Tregs from wild-type pregnant mice, which led to a significantly increased litter size (48). Alternatively, depleting CD25 ${ }^{+}$Tregs during the implantation period of nonsynergistically mated mice caused high fetal resorption (49). Depleting Tregs in the mid-gestation phase in non-sterile mice also resulted in high fetal resorption (50). In a systematic review of 17 studies on human pregnancy, it has been shown that the number and functionality of Tregs are diminished in women experiencing RPL, both in the peripheral blood and in the decidua, compared to control women (51). Similarly, in women with pre-eclampsia decreased Treg frequencies in both the periphery and the decidua and impairment in the signaling of peripheral blood Tregs have been found $(45,52,53)$.

Using extensive mass cytometry panels containing more than 38 immune cell markers, we have previously shown that there is great heterogeneity in immune cell subsets among the different trimesters (van der Zwan et al. submitted). Interestingly, five Treg-like clusters were found to be differently distributed over the three trimesters. This could be attributed to the developmental changes in the placenta, causing a constant change in the possible cell-cell interactions between immune cells and different EVT subsets that seem to exist over different trimesters (54). Apart from that, a deficit in Treg presence and functionality has been observed in pregnancy complications such as PE, infertility, and RPL (55). Such complications arise at different periods of pregnancy, i.e., during implantation, $<22-24$ weeks of gestation or throughout gestation $(56,57)$. Taken together, as both Treg subsets and the initiation of complications can be prominent in a particular time frame of gestation, it might be that disbalances in different Treg subsets could play a role in the onset of different complications. Therefore, it is important to investigate the presence and functioning of the wide range of Treg subsets present during pregnancy.

\section{ADVANCES IN TREG IDENTIFICATION}

Regulatory T cells were originally named suppressor cells (58). Ideas and insights changed over time, and suppressor cells have endured much debate. In 1983 it was shown in mice that both 
CD8 (Lyt-2 ${ }^{+}$) and CD4 (Lyt-2- ) suppressor cells were present that expressed the I-J molecule (59). When the I-J molecule turned out not to exist and suppressor cells could not be identified in any other way, interest in these cells waned. The arrival of novel molecular technologies propelled new knowledge, which made immunological tolerance become more evident and revived interest in $\mathrm{T}$ suppressor cells, now referred to as Tregs (60). In 2001, the FoxP3 gene was identified in scurfy mice and later as a key transcription factor for Treg cell development and function in both humans and mice $(61,62)$. Subsequently, several FoxP3 ${ }^{-}$Treg subsets were identified, as will be discussed below. Initially, it was hypothesized that Tregs could only be generated in the thymus (tTregs), but in the 2000s this concept was challenged by studies showing that Tregs could be induced from conventional $\mathrm{T}$ cells in the periphery (pTregs) $(63,64)$. It is thought that tTregs and pTregs function in distinct ways, recognize different types of antigens (autoantigens vs. foreign antigens), and are needed in different immunological events such as preventing $\mathrm{T}$ cell trafficking to an organ and preventing $\mathrm{T}$ cell priming by APC, respectively (65).

Because tTregs and pTregs can have different roles, there is a need for phenotypic markers to distinguish the two. While Helios and Nrp-1 have been proposed as markers for tTregs in mice $(66,67)$, it has been shown that Helios deficiency or Nrp-1 deficiency does not impede tTreg development $(65,68)$. Consequently, there is no consensus on which markers can distinguish tTregs from pTregs $(65,69,70)$. Helios is associated with the promoter regions of apoptosis/cell survival genes, and Helios deficient FoxP3 ${ }^{+}$Tregs show increased inflammatory cytokine expression, which suggests the importance of Helios in suppressing the production of effector cytokines (71). Even though Nrp-1 is not essential for tTreg development, it seems to increase Treg immunoregulatory properties, such as an increased capacity for tumor infiltration $(69,72)$. When comparing Nrp-1 and Helios there is no consistent overlap in expression of these markers (65). In humans, Helios is found on Tregs, but Nrp1 is not found on peripheral blood Tregs and can, therefore, be excluded as tTreg marker $(66,73)$. More recently CNS1 has been suggested to distinguish between tTregs and pTregs. However, since CNS1 is a FoxP3 enhancer, it is debatable whether this marker distinguishes FoxP ${ }^{-}$tTreg and pTreg populations $(74,75)$.

Treg subsets are often identified by their co-signaling molecules. Many Treg subsets express co-signaling molecules, such as ICOS, PD-1, TIGIT, and TIM-3, which upon interaction with their ligand can alter their function to either activation or senescence (76-78). These co-signaling molecules, which can be present on both FoxP3 ${ }^{+}$and FoxP3 ${ }^{-}$Tregs, have widely been discussed in several reviews (79-81). Similarly, the heterogeneity within FoxP3 ${ }^{+}$Tregs, generally described as $\mathrm{CD} 4{ }^{+} \mathrm{CD} 25^{+} \mathrm{CD} 127^{-}$in functional assays, has been extensively reviewed elsewhere (82-87). However, the heterogeneity within the FoxP ${ }^{-}$compartment has not been elaborated on and will be discussed here in the context of pregnancy. Besides co-signaling molecules, several soluble factors affect the action of Tregs and are produced by these cells to mediate their immune regulatory effects. These will first be briefly reviewed.

\section{SOLUBLE FACTORS}

\section{IL-10}

IL-10 is an immunomodulatory cytokine that is produced by many immune cells in the decidua, including most known Treg subsets. It has an effect on trophoblasts and innate- and adaptive immune cells within the decidua (88). Single nucleotide polymorphisms (SNPs) in the promoter region of IL-10 correlate with adverse pregnancy outcomes in humans (89). Next to that, the administration of recombinant IL-10 or IL-10 producing B cells to mice leads to reduced incidence of fetal resorption (90). Concomitantly, IL-10 null mice in sterile cages showed normal litter size, whereas administration of a danger signal in the form of a low dose of LPS to these mice resulted in increased fetal resorption $(91,92)$. These data suggest that IL-10 is an important mediator of immune regulation during pregnancy. In human pregnancy, decreased serum IL-10 levels or IL-10 production by PBMCs are associated with the occurrence of PE and RPL (93-98). This suggests that IL-10 producing immune cells are important for maintaining an uncomplicated pregnancy.

IL-10 induces expression of HLA-G on trophoblasts, which has direct and indirect immune suppressive effects (described below) (99). IL-10, together with HLA-G, can induce monocyte-derived DCs in vitro to differentiate into tolerogenic DCs (DC-10) that have immunosuppressive properties $(100,101)$. They exert their immunosuppressive properties by the production of IL-10, expression of HLA-G, and upregulation of inhibitory receptors for HLA-G (namely ILT2, ILT3, and ILT4). Furthermore, these tolerogenic DCs downregulate co-stimulatory molecules CD80 and CD86, as well as HLA-DR (102-104). DC-10s induce Tregs by their expression of ILT4 and by IL-10 production (105). Macrophages are also regulated by IL-10 (106). It has been shown that IL-10 acts on macrophages by controlling their metabolic pathways, causing activation, proliferation, and inflammatory responses to be inhibited $(106,107)$. Next to that, $\mathrm{CD}^{+} \mathrm{T}$ cell proliferation is suppressed by IL-10, antigen-experienced specific $\mathrm{CD} 4^{+} \mathrm{T}$ cells can be induced into an anergic state, and conventional $\mathrm{T}$ cells can be induced to convert to Tregs $(103,108-110)$.

\section{TGF- $\beta$}

TGF- $\beta$ is produced by and has an immunomodulatory effect on multiple cell types present in the decidua (111-120). In the early implantation phase, TGF- $\beta$ is important for trophoblast invasion in the endometrium $(121,122)$. In humans, TGF- $\beta$ serum levels are elevated in pregnant women compared to non-pregnant women, and serum levels are higher in early pregnancy compared to late pregnancy (123). However, women experiencing RPL display a decrease in TGF- $\beta$ serum levels compared to women undergoing elective termination for non-medical reasons (124). Interestingly, there are indications from mouse studies that TGF$\beta$ induced Tregs could prevent spontaneous abortion, but this effect needs to be elucidated further $(111,125)$.

TGF- $\beta$ can inhibit NK cell and $\mathrm{T}$ cell activation and proliferation by repressing the mammalian target of rapamycin (mTOR) signaling pathway $(126,127)$, and similarly, suppress activation of dNK cells (120). Since dNK cells are important 
contributors to angiogenesis at the maternal-fetal interface, their cytotoxicity needs to be suppressed but they should still be able to execute their role in angiogenesis. A balanced TGF- $\beta$ level may, therefore, be important to maintain correct functioning of dNK cells (120). Furthermore, TGF- $\beta$ can affect T cells directly by inhibiting their proliferation and differentiation $(128,129)$, and indirectly by its inhibitory effect on APCs. HLA-class II on APCs is downregulated, activation of macrophages is downregulated, and maturation of DCs is prevented by TGF- $\beta$ (116, 130-134). Next to that, the presence of TGF- $\beta$ is needed for the induction of several FoxP3 ${ }^{+}$and FoxP3 ${ }^{-}$Treg subsets by APCs (135-138).

\section{HLA-G}

As discussed above, HLA-G was first described on trophoblasts (1). Interestingly, also myeloid and lymphoid cells, such as the below described FoxP3 ${ }^{-}$HLA-G $^{+}$Treg, can express HLA-G and secrete sHLA-G (139-141). HLA-G is oligomorphic and has seven isoforms, of which some are membrane-bound (HLAG1 to -G4), and others are secreted as a soluble form (sHLAG5 to -G7) (142). Several polymorphisms in the untranslated region (UTR) of the $H L A-G$ gene have been associated with lower sHLA-G levels in both blood and seminal plasma $(143,144)$. In both PE and RPL, a reduction in serum sHLA-G levels has been observed compared to healthy control women (145-148). Together these observations highlight the possible importance of (s)HLA-G during pregnancy.

(s)HLA-G exerts its immunoregulatory effects on a wide variety of immune cells because of its interactions with several inhibitory receptors, of which ILT2 seems to be most prominent (149). Other receptors for (s)HLA-G are ILT4, KIR2DL4, and CD8. The ITL2 receptor is expressed on monocytes/macrophages, DCs, B cells, and some NK and T cells (150), while the ILT4 receptor is mainly present on macrophages, NK cells, and neutrophils $(150,151)$. Upon ILT2 or ILT4 binding to HLA-G, NK cells and $\mathrm{T}$ cells receive a signal that leads to inhibited killing capacity $(152-154)$. In CD8 ${ }^{+} \mathrm{T}$ cells, this inhibited killing capacity is reflected by the down-regulation of granzyme B expression (155). KIR2DL4 has been identified on $\mathrm{dNK}$ cells and some $\mathrm{T}$ cell subsets. Engagement of this receptor with sHLA-G results in activation and secretion of different types of cytokines and chemokines, but does not result in direct cytotoxicity (156). Binding of sHLA-G with KIR2DL4 on NK cells results in the upregulation of a restricted set of chemokines and cytokines that can promote vascular remodeling (156). CD8 is not only expressed by cytotoxic T cells but also by some NK cell subsets $(79,157)$. When sHLA-G binds to $\mathrm{CD} 8$, this interaction inhibits cytotoxic activity and triggers FasLmediated apoptosis in both the $\mathrm{CD}^{+} \mathrm{T}$ cells and $\mathrm{CD}^{+} \mathrm{NK}$ cells (158). Besides effector cells, APCs can also be affected by HLA-G. For example, in concert with IL-10, HLA-G induces DCs to differentiate into tolerogenic DC-10 cells $(100,101)$. Additionally, macrophages obtain a tolerogenic phenotype upon binding to HLA-G with their ILT2 or ILT4, and subsequently show reduced expression of HLA class II, CD80, and CD86. Such macrophages have been described to be similar to decidual macrophages as they also express IDO (159). Together this suggests that decidual macrophages are under the constant influence of HLA-G, produced by either trophoblasts or HLA$\mathrm{G}^{+}$Tregs.

\section{FOXP3- REGULATORY T CELLS}

\section{FoxP3- HLA-G+ Tregs}

In the lymphoid compartment, HLA-G expressing $\mathrm{CD}^{+}$and $\mathrm{CD}^{+}$cells show reduced proliferation in response to allogeneic and polyclonal stimuli (139). $\mathrm{CD}^{+} \mathrm{HLA}_{-} \mathrm{G}^{+} \mathrm{CD} 25^{-} \mathrm{FoxP}^{-}$ Tregs (Figures 2, 5, Table 1) suppress T cell proliferation through the expression of membrane-bound HLA-G1 and secretion of IL-10 and sHLA-G5 in a reversible, cell-contact independent and cell-contact dependent manner $(139,169)$. They have functionally been compared to other Treg populations such as FoxP3 ${ }^{+}$Tregs and $\operatorname{Tr} 1$ Tregs (discussed below), and represent a population that is distinct from tTregs (169-171). Interestingly, $\mathrm{CD}^{+}$and $\mathrm{CD}^{+} \mathrm{T}$ cells can also acquire a similar HLA$\mathrm{G}^{+}$phenotype in vitro through trogocytosis (160), meaning the uptake of membrane fragments from another cell. Resting and activated $\mathrm{CD} 25^{+} \mathrm{T}$ cells that acquire HLA-G1 expression by trogocytosis differ functionally from the HLA-G ${ }^{+}$tTregs, and they do not secrete sHLA-G5 and IL-10. They have been shown to exert their immune-suppressive capacity in a cell-contact dependent manner only (160), and will not be discussed further.

$\mathrm{HLA}_{-} \mathrm{G}^{+}$tTregs accumulate at sites of inflammation to regulate immune responses (172) and importantly, have also been found in the decidua $(141,173)$. CD4 ${ }^{+} \mathrm{HLA}-\mathrm{G}^{+}$Treg frequencies are increased in peripheral blood throughout pregnancy compared to non-pregnant controls $(45,141)$. Interestingly, sHLA-G serum levels are also increased during pregnancy, while these levels are decreased in complicated pregnancies compared to healthy pregnancies (145-148). However, it is unlikely that a direct correlation between $\mathrm{CD}^{+}{ }^{+} \mathrm{HLA}_{-\mathrm{G}^{+}}$Treg frequencies and serum sHLA-G levels exists, since other cells (in the placenta) produce sHLA-G as well. CD4 ${ }^{+} \mathrm{HLA}-\mathrm{G}^{+}$Treg frequencies within the $\mathrm{CD}^{+}{ }^{+} \mathrm{T}$ cell compartment are even higher in the decidua compared to those in peripheral blood $(141,173)$, suggesting a role in local immune regulation. In women with $\mathrm{PE}$, decidual $\mathrm{CD} 4{ }^{+} \mathrm{HLA}_{-\mathrm{G}}{ }^{+}$Tregs are decreased, whereas in the peripheral blood their numbers remain unchanged compared to healthy control pregnancies $(45,173)$, indicating that in a healthy pregnancy these cells are induced locally, but to a lesser extent during PE.

\section{Tr1 Treg}

Tr1 Tregs (Figures 3, 5, Table 1) suppresses T cell proliferation mainly through IL-10 and TGF- $\beta$ production. They also produce low amounts of IFN- $\gamma$, IL-5, and IL-2, and express granzyme B $(109,112,174)$. Next to cytokine production, they can suppress other immune cells in a cell-contact dependent manner by using their KIR receptors or ectoenzymes (161). Tr1 Tregs are peripherally induced upon chronic antigen stimulation in the presence of IL-10 (175). Both HLA-G and IL-10 provided by APCs, like DC-10 cells, play a role in Tr1 Treg induction (103), 


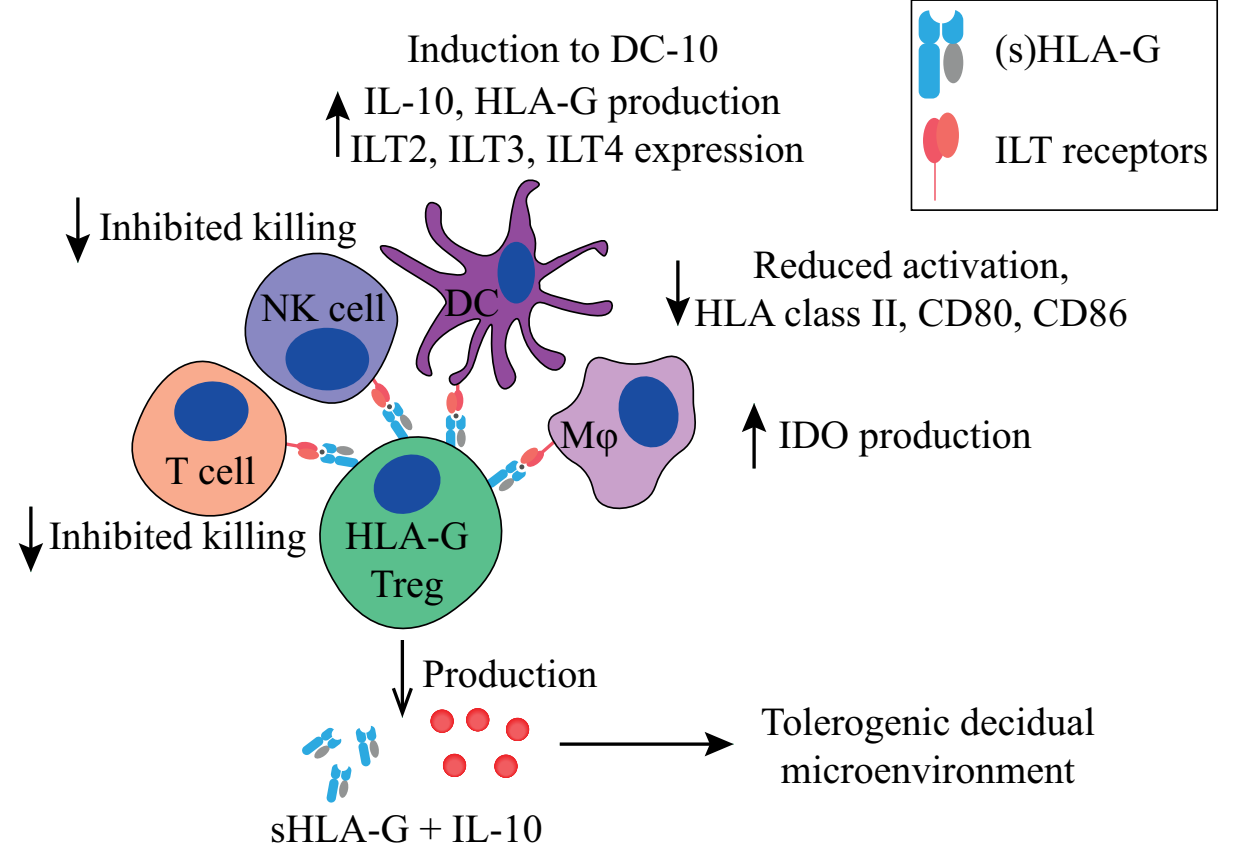

FIGURE 2 | Main tolerogenic mechanisms of the FoxP3 ${ }^{-} \mathrm{HLA}-\mathrm{G}^{+}$regulatory $T$ cell. $\mathrm{HLA}^{-\mathrm{G}^{+}}$regulatory $\mathrm{T}$ cells can suppress in a cell-contact dependent manner via HLA-G1. It inhibits the killing capacity of T cells and NK cells, downregulates HLA class II, CD80, and CD86 in DCs and macrophages, and makes them tolerogenic by inducing IDO production in macrophages and the induction of DCs to DC-10 cells. HLA-G+ regulatory T cells produce IL-10 and soluble HLA-G5 that helps to create a tolerogenic decidual microenvironment. HLA, human leukocyte antigen; NK, natural killer cell; DC, dendritic cell; IDO, indoleamine 2,3-dioxygenase; IL-10, interleukin-10; DC-10, tolerogenic DCs.

indicated by their reduced induction by DC-10s when anti-HLA$\mathrm{G}$ is added in vitro. Additionally, their induction is reverted when agonistic anti-ILT4 antibodies are added, but not when agonistic anti-ILT2 antibodies are added (103). Interestingly, EVTs are also able to induce Tr1-like cells via HLA-G directly (119).

Recently, co-expression of CD49b and LAG-3 has been described as phenotypic markers for Tr1 Tregs in mice and humans (176). This observation is under debate since a subsequent study only detected a small proportion of IL- $10^{+}$ Tregs co-expressing CD49b and LAG3 (177). Due to their lack of a clear phenotype, $\operatorname{Tr} 1$ Tregs are often described as Tr1-like cells, as they have similar properties, such as IL-10 production. Tr1 Tregs can express the co-signaling molecules PD-1, CTLA-4, TIM-3, and ICOS (136, 177-179), and several other molecules related to their function, including GARP, LAP, ectoenzyme CD39, and CD73 (180), as well as KIRs and ILT receptors. FoxP3 is only transiently expressed by $\operatorname{Tr} 1$ Tregs. Since functional $\operatorname{Tr} 1$ Tregs are found in patients who have a mutation in the FoxP3 gene, FoxP3 appears not to be required for their development (110, 174).

Tr1-like Tregs have been identified in peripheral blood and various tissues (181), including the human decidua (119). These Tregs express high levels of PD-1, express granzymes, and lack FoxP3. They produce IL-10 and IFN- $\gamma$, and thereby may have a similar suppressive mechanism as bona fide Tr1 Tregs (119). Similar to Tr1 Treg, decidual Tr1-like Treg induction by EVTs can be partially reverted when agonistic anti-HLA-G antibodies are added, but not by anti-ILT2 (119). Tr1 Tregs are able to selectively lyse APCs in a cell-contact dependent manner, but not B and T cells (161). Lysis of APCs can cause amplification of the tolerogenic process since decreased numbers of activated APCs will generally lead to less activation of $\mathrm{T}$ cells. For this, the Tr1 Treg needs HLA-class I recognition of the APC through its KIR receptors, CD54/LFA-1 mediated adhesion, CD58/CD2 interaction, as well as CD155/CD226 ligation (161). Furthermore, the $\operatorname{Tr} 1$ has been described to directly affect $\mathrm{T}$ cells by their expression of ectoenzyme CD39 and CD73, which disrupts the metabolic state of effector T cells (180).

\section{Th3 Tregs}

The main suppressive effects of Th3 Tregs (Figures 4, 5, Table 1) are mediated by TGF- $\beta$ production, in a cell-contact independent manner (135). Phenotypically these cells are CD25 ${ }^{-}$and FoxP3 ${ }^{-}$, they are thought to express Helios, and express LAP and GARP, which can be used as surrogate markers for TGF- $\beta$ production (182, 183). Th3 cells also produce IL-10, but unlike Tr1 Tregs, they produce this in conjunction with IL-4 $(113,184)$. Similar to Tr1 Tregs, Th3 Tregs are peripherally induced upon antigen stimulation (135). The mechanism underlying the induction into either Th3- or Tr1 Treg remains poorly understood and is thought to depend on their microenvironment during priming $(114,185)$. Another question that remains to be answered is whether Tr1 and Th3 Tregs truly represent different subsets or differentiation states and whether they differ depending on the microenvironment in which they reside.

With the limited markers identified so far, it is difficult to phenotypically identify Th3 Tregs, which may explain the limited number of articles describing the presence of the Th3 


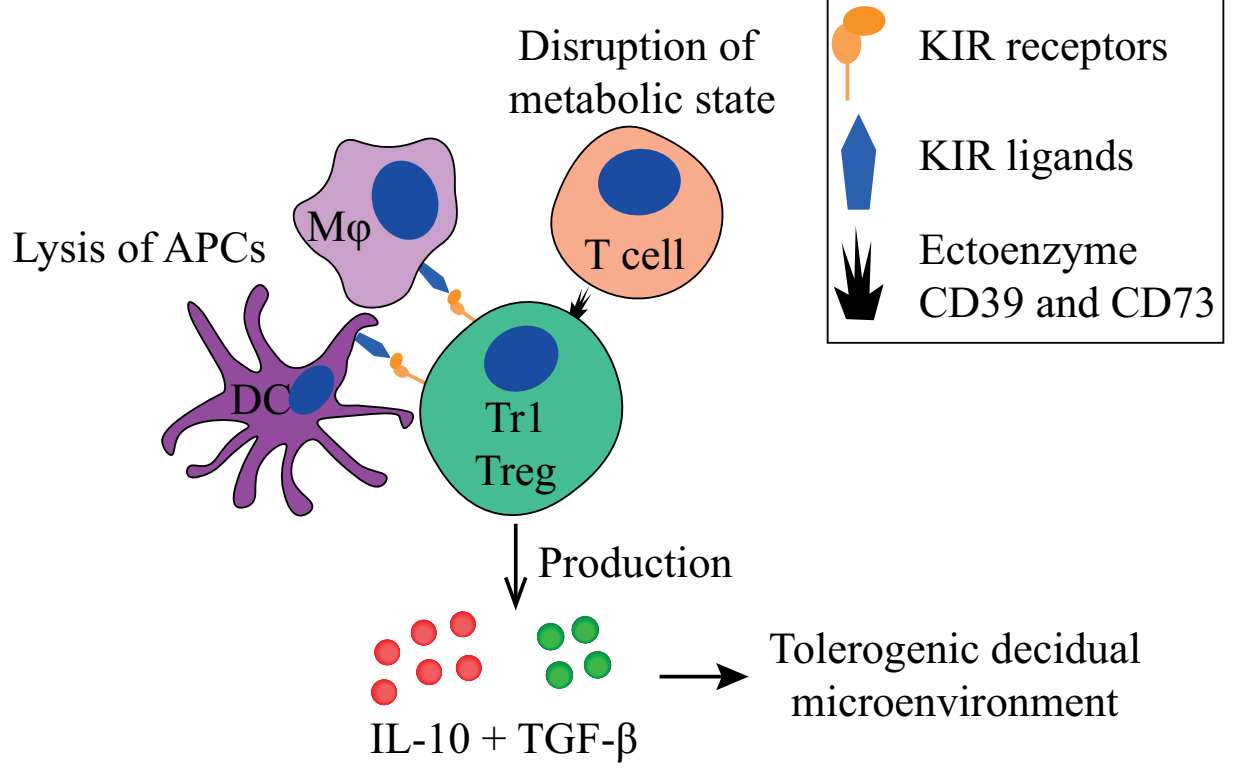

FIGURE 3 | Main tolerogenic mechanisms of the Tr1 regulatory T cell. Tr1 regulatory T cells can in a cell-contact dependent manner lyse APCs via their KIR receptors and disturb the metabolic state of T cells. They produce IL-10 and TGF- $\beta$ that helps to create a tolerogenic decidual microenvironment. APC, antigen-presenting cell; KIR, killer-cell immunoglobulin-like receptor; IL-10, interleukin-10; TGF- $\beta$, transforming growth factor-beta.

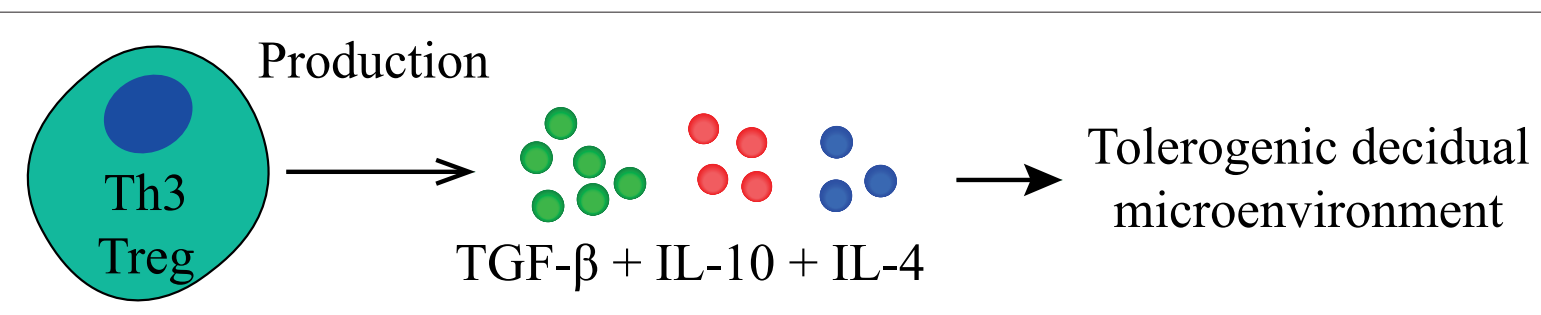

FIGURE 4 | Main tolerogenic mechanisms of the Th3 regulatory T cell. Th3 regulatory $T$ cells suppress in a cell-contact independent mechanism only by the production of TGF- $\beta$, IL-10 and differ here from the Tr1 regulatory T cell by the production of IL-4. TGF- $\beta$, transforming growth factor-beta; IL, interleukin.

cell during pregnancy. Dimova et al. observed in paired decidua and peripheral blood samples mRNA cytokine profiles similar to Th3, the first description of a possible presence of Th3 cells in the decidua (163). Importantly, no functional testing has been performed for Th3-like cells from the decidua, and their presence and role in pregnancy remains to be confirmed. Regardless, Th3 Treg was first described to have an important role in oral tolerance (182). Interestingly, exposure to semen through oral sex has been proposed to be beneficial for subsequent pregnancy outcomes in couples experiencing PE or RPL (186188), providing a possible mechanistic explanation for this effect.

\section{Other Treg Populations}

Besides FoxP3 ${ }^{-}$HLA-G $^{+}$, Tr1, and Th3 Tregs, other immune regulatory $\mathrm{T}$ cell populations that have been described, albeit to a lesser extent, include $\mathrm{CD} 8^{+}$Tregs, nitric oxide (NO) induced FoxP3 $^{-}$Tregs, TIGIT $^{+}$Tregs, FoxP3 ${ }^{\text {dim }}$ Tregs, and $\gamma \delta \mathrm{T}$ cells (Figure 5, Table 1).
$\mathrm{CD}^{+}$Tregs are increasingly being recognized, even though they remain difficult to identify as there is no consensus on their phenotype. Both FoxP3 ${ }^{+}$and FoxP3 ${ }^{-} \mathrm{CD}^{+}$Tregs have been described to have suppressive activities, indicating there also is heterogeneity in the $\mathrm{CD}^{+}$Treg population (189). Shao et al. showed that a $\mathrm{CD}^{+}$Treg subset can be activated by trophoblast cells. This activation appears not to be HLA restricted since their expansion is unaffected when cultured in the presence of pan-HLA class I blocking antibodies (164). When cultured with PBMCs, these $\mathrm{CD}^{+}$Tregs suppress the secretion of immunoglobulins in a cell-contact dependent manner, as shown using a trans-well system. While humoral immunity seemed to be dampened, these $\mathrm{CD} 8^{+}$Tregs did not have any suppressive effect on effector $\mathrm{T}$ cells. Phenotypically these cells can be identified as being $\mathrm{CD}_{101^{+}}$and $\mathrm{CD} 103^{+}$(164). Even though in a mixed lymphocyte reaction these CD8+ Tregs do not appear to suppress $\mathrm{CD}^{+}{ }^{+}$and $\mathrm{CD} 8^{+} \mathrm{T}$ cells, they could potentially be important for preventing formation and suppressing production of IPA-specific antibodies. 
TABLE 1 | Overview of FoxP3- immune regulating T cells discussed in this review, how they are induced or activated, their main suppressive mechanism and how they function, their localization, animal models depletion assays, master genes for differentiation, and cell volume changes in complicated pregnancies.

\begin{tabular}{|c|c|c|c|c|c|c|c|}
\hline Subset & $\begin{array}{l}\text { Induction/ } \\
\text { activation }\end{array}$ & $\begin{array}{l}\text { Suppressive } \\
\text { mechanism }\end{array}$ & Function & Localization & $\begin{array}{l}\text { Depletion in } \\
\text { animal models }\end{array}$ & $\begin{array}{l}\text { Master genes of } \\
\text { differentiation }\end{array}$ & $\begin{array}{l}\text { Cell volume } \\
\text { changes in } \\
\text { complications }\end{array}$ \\
\hline $\begin{array}{l}\text { CD4 }^{+} \text {HLA- }^{-} \\
\text {G }^{+} \text {Treg } \\
(139,160)\end{array}$ & $\begin{array}{l}\text { Natural occurring } \\
(139)\end{array}$ & $\begin{array}{l}\text { Secretion of } \\
\text { sHLA-G and IL-10 } \\
\text { (139), and cell } \\
\text { interaction with } \\
\text { HLA-G (160) }\end{array}$ & $\begin{array}{l}\text { Induction of HLA-G } \\
\text { expression by } \\
\text { trophoblasts, DC-10s } \\
\text { and Tregs by IL-10 } \\
\text { Inhibition of } \\
\text { macrophages, NK cells } \\
\text { and T cell killing }\end{array}$ & $\begin{array}{l}\text { Found in } \\
\text { peripheral blood } \\
(45) \text { and decidua } \\
(141)\end{array}$ & $\begin{array}{l}\text { Has not been } \\
\text { performed }\end{array}$ & Not known & $\begin{array}{l}\text { Found to be } \\
\text { increased in } \\
\text { peripheral blood of } \\
\text { pre-eclampsia } \\
\text { patients (45) }\end{array}$ \\
\hline $\begin{array}{l}\text { Tr1-(like) Treg } \\
(109,119)\end{array}$ & $\begin{array}{l}\text { Via trogocytosis } \\
(160)\end{array}$ & $\begin{array}{l}\text { Secretion of IL-10 } \\
\text { and TGF- } \beta \text {, and } \\
\text { cell interaction } \\
(136,161)\end{array}$ & $\begin{array}{l}\text { Induction of HLA-G } \\
\text { expression by } \\
\text { trophoblasts, DC-10s } \\
\text { and Tregs by IL-10 } \\
\text { Lysis of APCs, } \\
\text { disruption of metabolic } \\
\text { state of T cells }\end{array}$ & $\begin{array}{l}\text { Found in } \\
\text { peripheral blood } \\
\text { and decidua (119) }\end{array}$ & $\begin{array}{l}\text { Has not been } \\
\text { performed }\end{array}$ & Not known & $\begin{array}{l}\text { Has not been } \\
\text { described }\end{array}$ \\
\hline $\begin{array}{l}\text { Th3 Treg } \\
\text { (162) }\end{array}$ & $\begin{array}{l}\text { By APC in an } \\
\text { IL-10 dominant } \\
\text { microenvironment } \\
(110)\end{array}$ & $\begin{array}{l}\text { Secretion of TGF- } \beta \\
\text { and IL-10 (162) }\end{array}$ & $\begin{array}{l}\text { Induction of HLA-G } \\
\text { expression by } \\
\text { trophoblasts, DC-10s } \\
\text { and Tregs by IL-10 } \\
\text { Inhibition of NK cell and } \\
\text { T cells and APC } \\
\text { by TGF- } \beta\end{array}$ & $\begin{array}{l}\text { Found in the } \\
\text { decidua (163) }\end{array}$ & $\begin{array}{l}\text { Has not been } \\
\text { performed }\end{array}$ & Not known & $\begin{array}{l}\text { Has not been } \\
\text { described }\end{array}$ \\
\hline $\begin{array}{l}\text { CD8+ Treg } \\
\text { (59) }\end{array}$ & $\begin{array}{l}\text { By APC in } \\
\text { presence of TGF- } \beta \\
\text { and IL-4 } \\
(113,135)\end{array}$ & $\begin{array}{l}\text { Suppress the } \\
\text { secretion of } \\
\text { immunoglobulins } \\
(164)\end{array}$ & $\begin{array}{l}\text { Prevent formation and } \\
\text { suppressing production } \\
\text { of IPA-specific } \\
\text { antibodies. }\end{array}$ & $\begin{array}{l}\text { Found in } \\
\text { peripheral blood } \\
\left(\mathrm{CD} 8^{+} \mathrm{HLA}-\mathrm{G}^{+}\right. \\
\text {Treg) (45) and } \\
\text { decidua (164) }\end{array}$ & $\begin{array}{l}\text { Has not been } \\
\text { performed }\end{array}$ & Not known & $\begin{array}{l}\mathrm{CD}^{+} \mathrm{HLA}-\mathrm{G}^{+} \\
\text {Treg are increased } \\
\text { in peripheral blood } \\
\text { of pre-eclampsia } \\
\text { patients (45) }\end{array}$ \\
\hline NO-Treg (165) & $\begin{array}{l}\mathrm{CD}_{101}+\mathrm{CD}_{103}^{+} \\
\text {are induced by } \\
\text { trophoblasts (164) }\end{array}$ & $\begin{array}{l}\text { Secretion of IL-10 } \\
(165,166)\end{array}$ & $\begin{array}{l}\text { Induction of HLA-G } \\
\text { expression by } \\
\text { trophoblasts, DC-10s } \\
\text { and Tregs by IL-10. }\end{array}$ & $\begin{array}{l}\text { Found in } \\
\text { peripheral blood } \\
(165)\end{array}$ & $\begin{array}{l}\text { Has not been } \\
\text { performed }\end{array}$ & Not known & $\begin{array}{l}\text { Has not been } \\
\text { described }\end{array}$ \\
\hline $\begin{array}{l}\text { TIGIT+ Treg } \\
(119)\end{array}$ & $\begin{array}{l}\text { Depends on nitric } \\
\text { oxide, p53, IL-2, } \\
\text { and OX-40 (165) }\end{array}$ & $\begin{array}{l}\text { Secretion of IFN } \gamma \\
\text { and IL-2 (119) }\end{array}$ & $\begin{array}{l}\text { Induction of IL-10 } \\
\text { production by APCs. } \\
\text { Suppression of CD4 }{ }^{+} \\
\text {effector T cells }\end{array}$ & $\begin{array}{l}\text { Found in decidua } \\
\text { (119) }\end{array}$ & $\begin{array}{l}\text { Has not been } \\
\text { performed }\end{array}$ & Not known & $\begin{array}{l}\text { Has not been } \\
\text { described }\end{array}$ \\
\hline $\begin{array}{l}\mathrm{V} \delta 1^{+} \gamma \delta \mathrm{T} \text { cell } \\
(167)\end{array}$ & Unknown & $\begin{array}{l}\text { Secretion of IL-10 } \\
\text { and TGF- } \beta \text { (115) }\end{array}$ & $\begin{array}{l}\text { Induction of HLA-G } \\
\text { expression by } \\
\text { trophoblasts, DC-10s } \\
\text { and Tregs by IL-10 } \\
\text { Inhibition of NK cell and } \\
\text { T cells and APC } \\
\text { by TGF- } \beta\end{array}$ & $\begin{array}{l}\text { Found in } \\
\text { peripheral blood } \\
\text { and decidua (168) }\end{array}$ & $\begin{array}{l}\text { Has not been } \\
\text { performed }\end{array}$ & Not known & $\begin{array}{l}\text { Decreased } \\
\text { amount in an } \\
\text { abortion prone } \\
\text { mice model (111) }\end{array}$ \\
\hline
\end{tabular}

Niedbala et al. described NO-induced Tregs (NOTregs) in mice (165). These cells are characterized as $\mathrm{CD} 4^{+} \mathrm{CD} 25^{+} \mathrm{GITR}^{+} \mathrm{CD} 27^{+} \mathrm{T}^{- \text {bet }}{ }^{\text {low }}, \mathrm{GATA}^{+}$, and FoxP3 ${ }^{-}$, and they are induced from $\mathrm{CD} 4{ }^{+} \mathrm{CD} 25^{-} \mathrm{T}$ cells via $\mathrm{p} 53$, IL-2, and OX-40 (165). Experimentally, the development of NO-Tregs was induced when using adoptive transfer of $\mathrm{CD} 4{ }^{+} \mathrm{CD} 25^{-}$ $\mathrm{T}$ cells into SCID mice, together with application of an NO synthase inhibitor. NO-Tregs produce IL-4 and IL-10, but no IL-2, TGF- $\beta$, or IFN- $\gamma$. Addition of antagonistic anti-IL4 antibodies led to reduced proliferation of NO-Tregs, whereas blocking IL-10 blocked their suppressive effect on $\mathrm{CD} 4{ }^{+} \mathrm{CD} 25^{-}$ cell differentiation $(165,166)$. These data suggest that NO-Tregs suppress through IL-10, in a cell-contact independent manner.
While NO-Tregs has not yet been studied in the context of pregnancy, NO appears to be involved in pregnancy with NO levels fluctuating throughout the different gestational ages and being lower during PE (190-193). It would, therefore, be interesting to retrospectively study first-trimester blood samples of women who develop PE, to test if NO levels are already lower at this early time point of pregnancy, and to study NO-Treg formation in these patients in comparison to healthy controls.

Salvany-Celades et al. identified three types of functional Tregs in the decidua, of which two subsets were negative or low for FoxP3 (119). One of these is the PD-1 high, Tr1like cell, which has been described above. The second is the 


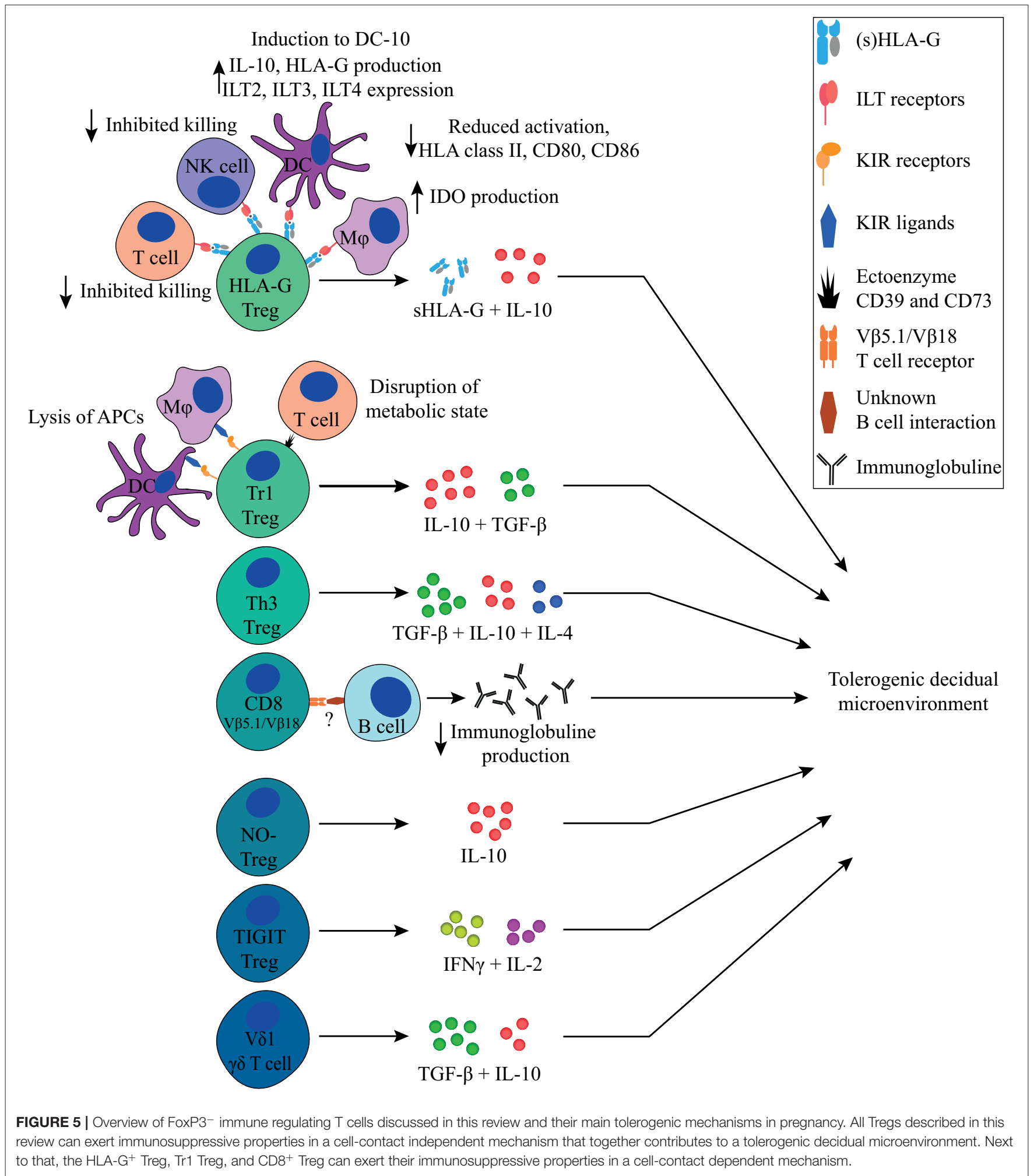

TIGIT $^{+}$Treg that is characterized by TIGIT positivity, low expression of $\mathrm{CD} 25$ and FoxP3, and intermediate expression of PD-1. TIGIT ${ }^{+}$Tregs express high levels of IFN- $\gamma$ and IL-2, and low levels of IL-10. TIGIT $^{+}$Tregs mainly suppress $\mathrm{CD} 4^{+}$ effector $\mathrm{T}$ cells in proliferation assays, but not consistently $\mathrm{CD}^{+}$effector $\mathrm{T}$ cells. Interestingly, $\mathrm{TIGIT}^{+}$Tregs seem to vary in their characteristics, depending on the trimester in which they are encountered (119): first-trimester TIGIT $^{+}$ 
Tregs show an increased expression of IL-10 compared to term TIGIT $^{+}$Tregs. This difference in trimesters could be due to the microenvironment influencing their phenotype, or because they truly represent different subsets. TIGIT has been described to be expressed on multiple Treg subsets, and it can bind CD155 on APCs, which thereby increases their IL-10 production $(194,195)$. Binding of TIGIT induces Tregs to produce IL-10 and fibrinogen-like protein 2 (Fgl2). By usage of Fgl2 the Tregs obtain the capacity to suppress Th1 and Th17 cells in vitro, but not Th2 cells $(77,195)$. It would be interesting to determine the presence of TIGIT $^{+}$ Tregs during pregnancy complications and to investigate their possible role in providing a tolerogenic microenvironment in successful pregnancies.

In the first-trimester decidua, $\gamma \delta$ T cells produce high amounts of IL-10 and TGF- $\beta$ (115, 196). As described above, these cytokines are important for establishing an immune suppressive microenvironment in the decidua. Transfer of uterine $\gamma \delta \mathrm{T}$ cell culture supernatant, containing a high concentration of TGF- $\beta$, into the uterus of mice before pregnancy prevents fetal resorption (111). Terzieva et al. identified the TCR repertoire from decidual $\gamma \delta \mathrm{T}$ cells and compared this to the repertoire of $\gamma \delta \mathrm{T}$ cells in peripheral blood. In $1^{\text {st }}$ and $3^{\text {rd }}$ trimester decidua they mostly found $\mathrm{V} \delta 1^{+} \mathrm{TCR}$, whereas this particular $\delta$ chain was hardly present in the peripheral blood (168). $\mathrm{V} \delta 1^{+}$ $\mathrm{T}$ cells are described to have a tolerogenic effect $(167,197)$. The possible role of $\gamma \delta \mathrm{T}$ cells in pregnancy is further suggested by another study showing higher numbers of $\gamma \delta$ T cells in peripheral blood from women experiencing RPL compared to controls. The specific presence of the V $\delta 1$ chain was not investigated (198). It would be interesting to determine the frequency and immunesuppressive effect of $\mathrm{V} \delta 1^{+} \mathrm{T}$ cells in the decidua of women experiencing RPL compared to women with elective termination of pregnancy.

\section{CONCLUDING REMARKS}

In this review we have discussed several types of Tregs that may contribute to a tolerogenic environment in the decidua (Figure 5, Table 1) besides FoxP3 ${ }^{+}$Tregs. Decidual Tregs seem to assist other cells in creating and maintaining a microenvironment where inflammatory signals are generally overruled by tolerogenic signals. Next to Tregs, this tolerogenic microenvironment is established and maintained by factors from paternal, maternal and fetal origin. Paternal contribution to this tolerogenic microenvironment comes early on from seminal fluid that contains tolerogenic factors such as TGF- $\beta$ and paternal antigens for priming. Fetal trophoblasts contribute by their expression of tolerogenic HLA-G and HLA-E molecules, galectins, and PD-L1, and by their production of sHLA-G, IDO, and TGF- $\beta$. Next to this, the maternal contribution in maintaining a tolerogenic microenvironment in the decidua is provided by the decidual immune cells, which do not have an activated phenotype and produce IDO, TGF- $\beta$, IL-10, and sHLA-G.

It remains to be elucidated which mechanisms exactly attract Tregs to the decidua, if they are activated locally by APCs in the decidua or in the lymph nodes, where they proliferate, and if they are specific for fetal antigens. In mice, it has been shown that fetus-specific Tregs are already detectable in the uterine draining lymph nodes shortly after semen exposure and that their numbers increase upon pregnancy (199). While this could be similar in the human situation, in vitro fertilization with donor semen, where there is no paternal semen exposure, often results in a healthy uncomplicated pregnancy, albeit at a lower rate than in naturally conceived pregnancies (200). More information on the basic mechanisms of FoxP3 ${ }^{-}$Tregs, as well as how they are initiated, is needed to provide insight in the deviations in frequencies or functionality of FoxP3 ${ }^{-}$Treg subsets in pregnancy complications. Likewise, from a therapeutic point of view such basic mechanisms need to be clarified before possible novel therapeutic strategies can be developed. These therapies could be based on therapy designs similar to those proposed for FoxP3 ${ }^{+}$Tregs, such as infusion of Tregs or application of the cytokines needed for induction of specific Treg subsets (201).

While it is clear that FoxP3 ${ }^{+}$Tregs play a role in maintaining pregnancy, the relevance of the different types of FoxP3 ${ }^{-}$Tregs herein needs to be established. FoxP3 ${ }^{-}$Tregs with proven suppressive capacities are found in the decidua and are, therefore, likely to contribute to the tolerogenic microenvironment. However, studies such as depletion assays in mice need to be performed to confirm whether they play a non-redundant role in maintaining a healthy pregnancy. Since pregnancy is crucial for the existence of mankind, it is not surprising that there would be multiple mechanisms in play to establish a regulatory microenvironment to maintain a healthy pregnancy. Pregnancy complications for which no clear cause can be identified do occur, and it is plausible that many of these are related to a disbalance in maternal immune regulation. It would be helpful to get a better understanding of the function of all regulatory $\mathrm{T}$ cells present in the decidua, to be able to recognize their relevance in healthy and complicated pregnancies. As such, the use of multiple omics techniques to identify the decidual microenvironment by a holistic approach could give insights in the presence, frequency, and distribution of the different types of Tregs in pregnancy [(32, 202, 203); van der Zwan et al., submitted]. It is important to note that the time point of sampling is a crucial factor in such experiments, given the dynamic nature of the placental microenvironment.

\section{AUTHOR CONTRIBUTIONS}

JK contributed to the content design, writing the manuscript, and preparing the figures. FC, $\mathrm{SH}$, and ME supervised the project and participated in critical discussions and evaluations of the text of the manuscript. 


\section{REFERENCES}

1. Ellis SA, Palmer MS, McMichael AJ. Human trophoblast and the choriocarcinoma cell line BeWo express a truncated HLA Class I molecule. J Immunol. (1990) 144:731-5.

2. Mallet V, Blaschitz A, Crisa L, Schmitt C, Fournel S, King A, et al. HLA$\mathrm{G}$ in the human thymus: a subpopulation of medullary epithelial but not CD83(+) dendritic cells expresses HLA-G as a membrane-bound and soluble protein. Int Immunol. (1999) 11:889-98. doi: 10.1093/intimm/1 1.6.889

3. Le Discorde M, Moreau P, Sabatier P, Legeais JM, Carosella ED. Expression of HLA-G in human cornea, an immune-privileged tissue. Hum Immunol. (2003) 64:1039-44. doi: 10.1016/j.humimm.2003.08.346

4. Cirulli V, Zalatan J, McMaster M, Prinsen R, Salomon DR, Ricordi C, et al. The class I HLA repertoire of pancreatic islets comprises the nonclassical class Ib antigen HLA-G. Diabetes. (2006) 55:1214-22. doi: $10.2337 / \mathrm{db} 05-0731$

5. Papuchova H, Meissner TB, Li Q, Strominger JL, Tilburgs T. The Dual Role of HLA-C in Tolerance and Immunity at the Maternal-Fetal Interface. Front Immunol. (2019) 10:2730. doi: 10.3389/fimmu.2019.02730

6. Tilburgs T, Scherjon SA, van der Mast BJ, Haasnoot GW, Versteeg VDVMM, Roelen DL, et al. Fetal-maternal HLA-C mismatch is associated with decidual $\mathrm{T}$ cell activation and induction of functional $\mathrm{T}$ regulatory cells. $J$ Reprod Immunol. (2009) 82:148-57. doi: 10.1016/j.jri.2009.05.003

7. Apps R, Murphy SP, Fernando R, Gardner L, Ahad T, Moffett A. Human leucocyte antigen. (HLA) expression of primary trophoblast cells and placental cell lines, determined using single antigen beads to characterize allotype specificities of anti-HLA antibodies. Immunology. (2009) 127:26-39. doi: 10.1111/j.1365-2567.2008.03019.x

8. Hackmon R, Pinnaduwage L, Zhang J, Lye SJ, Geraghty DE, Dunk CE. Definitive class I human leukocyte antigen expression in gestational placentation: HLA-F, HLA-E, HLA-C, and HLA-G in extravillous trophoblast invasion on placentation, pregnancy, and parturition. Am J Reprod Immunol. (2017) 77. doi: 10.1111/aji.12643

9. Rouas-Freiss N, Goncalves RM, Menier C, Dausset J, Carosella ED. Direct evidence to support the role of HLA-G in protecting the fetus from maternal uterine natural killer cytolysis. Proc Natl Acad Sci USA. (1997) 94:11520-5. doi: 10.1073/pnas.94.21.11520

10. Hunt JS, Petroff MG, McIntire RH, Ober C. HLA-G and immune tolerance in pregnancy. FASEB J. (2005) 19:681-93. doi: 10.1096/fj.04-2078rev

11. Tilburgs T, Crespo AC, van der Zwan A, Rybalov B, Raj T, Stranger B, et al. Human HLA-G plus extravillous trophoblasts: immune-activating cells that interact with decidual leukocytes. Proc Natl Acad Sci USA. (2015) 112:7219-24. doi: 10.1073/pnas.1507977112

12. Braud VM, Allan DS, O'Callaghan CA, Soderstrom K, D'Andrea A, Ogg GS, et al. HLA-E binds to natural killer cell receptors CD94/NKG2A, B and C. Nature. (1998) 391:795-9. doi: 10.1038/35869

13. Blaschitz A, Hutter H, Dohr G. HLA Class I protein expression in the human placenta. Early Pregnancy. (2001) 5:67-9.

14. Apps R, Gardner L, Traherne J, Male V, Moffett A. Natural-killer cell ligands at the maternal-fetal interface: UL-16 binding proteins, MHC class-I chain related molecules, HLA-F and CD48. Hum Reprod. (2008) 23:2535-48. doi: 10.1093/humrep/den223

15. Clark DA, Keil A, Chen Z, Markert U, Manuel J, Gorczynski RM. Placental trophoblast from successful human pregnancies expresses the tolerance signaling molecule, CD200 (OX-2). Am J Reprod Immunol. (2003) 50:18795. doi: 10.1034/j.1600-0897.2003.00086.x

16. Abrahams VM, Straszewski-Chavez SL, Guller S, Mor G. First trimester trophoblast cells secrete Fas ligand which induces immune cell apoptosis. Mol Hum Reprod. (2004) 10:55-63. doi: 10.1093/molehr/gah006

17. Petroff MG, Kharatyan E, Torry DS, Holets L. The immunomodulatory proteins $\mathrm{B} 7-\mathrm{DC}, \mathrm{B} 7-\mathrm{H} 2$, and $\mathrm{B} 7-\mathrm{H} 3$ are differentially expressed across gestation in the human placenta. Am J Pathol. (2005) 167:465-73. doi: 10.1016/S0002-9440(10)62990-2

18. Jones RL, Stoikos C, Findlay JK, Salamonsen LA. TGF-beta superfamily expression and actions in the endometrium and placenta. Reproduction. (2006) 132:217-32. doi: 10.1530/rep.1.01076
19. Lu B, Teng X, Fu G, Bao L, Tang J, Shi H, et al. Analysis of PD-L1 expression in trophoblastic tissues and tumors. Hum Pathol. (2019) 84:20212. doi: 10.1016/j.humpath.2018.10.001

20. Yeung AW, Terentis AC, King NJ, Thomas SR. Role of indoleamine 2,3-dioxygenase in health and disease. Clin Sci. (2015) 129:601-72. doi: $10.1042 / C S 20140392$

21. Balogh A, Toth E, Romero R, Parej K, Csala D, Szenasi NL, et al. Placental galectins are key players in regulating the maternal adaptive immune response. Front Immunol. (2019) 10:1240. doi: 10.3389/fimmu.2019.01240

22. Ramhorst RE, Giribaldi L, Fraccaroli L, Toscano MA, Stupirski JC, Romero $\mathrm{MD}$, et al. Galectin-1 confers immune privilege to human trophoblast: implications in recurrent fetal loss. Glycobiology. (2012) 22:1374-86. doi: $10.1093 /$ glycob/cws104

23. Than NG, Romero R, Goodman M, Weckle A, Xing J, Dong Z, et al. A primate subfamily of galectins expressed at the maternal-fetal interface that promote immune cell death. Proc Natl Acad Sci USA. (2009) 106:9731-6. doi: 10.1073/pnas.0903568106

24. Blois SM, Ilarregui JM, Tometten M, Garcia M, Orsal AS, Cordo-Russo R, et al. A pivotal role for galectin-1 in fetomaternal tolerance. Nat Med. (2007) 13:1450-7. doi: $10.1038 / \mathrm{nm} 1680$

25. Moldenhauer LM, Diener KR, Thring DM, Brown MP, Hayball JD, Robertson SA. Cross-presentation of male seminal fluid antigens elicits T cell activation to initiate the female immune response to pregnancy. J Immunol. (2009) 182:8080-93. doi: 10.4049/jimmunol.0804018

26. Sharkey DJ, Tremellen KP, Jasper MJ, Gemzell-Danielsson K, Robertson SA. Seminal fluid induces leukocyte recruitment and cytokine and chemokine mRNA expression in the human cervix after coitus. J Immunol. (2012) 188:2445-54. doi: 10.4049/jimmunol.1102736

27. Bulmer JN, Morrison L, Longfellow M, Ritson A, Pace D. Granulated lymphocytes in human endometrium: histochemical and immunohistochemical studies. Hum Reprod. (1991) 6:791-8. doi: 10.1093/oxfordjournals.humrep.a137430

28. Heikkinen J, Mottonen M, Alanen A, Lassila O. Phenotypic characterization of regulatory $\mathrm{T}$ cells in the human decidua. Clin Exp Immunol. (2004) 136:373-8. doi: 10.1111/j.1365-2249.2004.02441.x

29. Williams PJ, Searle RF, Robson SC, Innes BA, Bulmer JN. Decidual leucocyte populations in early to late gestation normal human pregnancy. J Reprod Immunol. (2009) 82:24-31. doi: 10.1016/j.jri.2009.08.001

30. Bulmer JN, Williams PJ, Lash GE. Immune cells in the placental bed. Int $J$ Dev Biol. (2010) 54:281-94. doi: 10.1387/ijdb.082763jb

31. Gomez-Lopez N, Guilbert LJ, Olson DM. Invasion of the leukocytes into the fetal-maternal interface during pregnancy. J Leukoc Biol. (2010) 88:625-33. doi: $10.1189 /$ jlb.1209796

32. Vento-Tormo R, Efremova M, Botting RA, Turco MY, VentoTormo M, Meyer KB, et al. Single-cell reconstruction of the early maternal-fetal interface in humans. Nature. (2018) 563:347-53. doi: 10.1038/s41586-018-0698-6

33. Moldenhauer LM, Hayball JD, Robertson SA. Utilising T cell receptor transgenic mice to define mechanisms of maternal $\mathrm{T}$ cell tolerance in pregnancy. J Reprod Immunol. (2010) 87:1-13. doi: 10.1016/j.jri.2010.05.007

34. Lissauer D, Piper K, Goodyear O, Kilby MD, Moss PA. Fetal-specific $\mathrm{CD} 8+$ cytotoxic $\mathrm{T}$ cell responses develop during normal human pregnancy and exhibit broad functional capacity. J Immunol. (2012) 189:1072-80. doi: 10.4049/jimmunol.1200544

35. Tilburgs T, Strominger JL. CD8+ effector $\mathrm{T}$ cells at the fetal-maternal interface, balancing fetal tolerance and antiviral immunity. Am J Reprod Immunol. (2013) 69:395-407. doi: 10.1111/aji.12094

36. Nakajima H, Mano Y, Tokunaga E, Nozue G. Influence of previous pregnancy on maternal response to foetal antigens. Tissue Antigens. (1982) 19:92-4. doi: 10.1111/j.1399-0039.1982.tb01421.x

37. Regan L, Braude PR. Is antipaternal cytotoxic antibody a valid marker in the management of recurrent abortion? Lancet. (1987) 2:1280. doi: 10.1016/S0140-6736(87)91896-4

38. Regan L, Braude PR, Hill DP. A prospective study of the incidence, time of appearance and significance of anti-paternal lymphocytotoxic antibodies in human pregnancy. Hum Reprod. (1991) 6:294-8. doi: 10.1093/oxfordjournals.humrep.a137325 
39. Pietra G, Romagnani C, Manzini C, Moretta L, Mingari MC. The emerging role of HLA-E-restricted CD8 $+\mathrm{T}$ lymphocytes in the adaptive immune response to pathogens and tumors. J Biomed Biotechnol. (2010) 2010:907092. doi: 10.1155/2010/907092

40. van Kampen CA, Versteeg-van der Voort Maarschalk MFJ, LangerakLangerak J, van Beelen E, Roelen DL, Claas FHJ. Pregnancy can induce long-persisting primed CTLs specific for inherited paternal HLA antigens. Human Immunol. (2001) 62:201-7. doi: 10.1016/S0198-8859(01)00209-9

41. Agrawal S, Pandey MK, Mandal S, Mishra L, Agarwal S. Humoral immune response to an allogenic foetus in normal fertile women and recurrent aborters. BMC Pregn Childbirth. (2002) 2:6. doi: 10.1186/1471-2393-2-6

42. Lee J, Romero R, Xu Y, Miranda J, Yoo W, Chaemsaithong P, et al. Detection of anti-HLA antibodies in maternal blood in the second trimester to identify patients at risk of antibody-mediated maternal anti-fetal rejection and spontaneous preterm delivery. Am J Reprod Immunol. (2013) 70:162-75. doi: 10.1111/aji.12141

43. Meuleman $\mathrm{T}$, van Beelen E, Kaaja RJ, van Lith JM, Claas FH, Bloemenkamp KW. HLA-C antibodies in women with recurrent miscarriage suggests that antibody mediated rejection is one of the mechanisms leading to recurrent miscarriage. J Reprod Immunol. (2016) 116:28-34. doi: 10.1016/j.jri.2016.03.003

44. Somerset DA, Zheng Y, Kilby MD, Sansom DM, Drayson MT. Normal human pregnancy is associated with an elevation in the immune suppressive CD25+ CD4+ regulatory T-cell subset. Immunology. (2004) 112:38-43. doi: 10.1111/j.1365-2567.2004.01869.x

45. Zare M, Namavar Jahromi B, Gharesi-Fard B. Analysis of the frequencies and functions of CD4(+)CD25(+)CD127(low/neg), CD4(+)HLA-G(+), and CD8 $(+)$ HLA-G(+) regulatory $\mathrm{T}$ cells in pre-eclampsia. J Reprod Immunol. (2019) 133:43-51. doi: 10.1016/j.jri.2019.06.002

46. Tilburgs T, Roelen DL, van der Mast BJ, van Schip JJ, Kleijburg C, de GrootSwings GM, et al. Differential distribution of CD4(+)CD25(bright) and CD8(+)CD28(-) T-cells in decidua and maternal blood during human pregnancy. Placenta. (2006) 27(Suppl. A):S47-53. doi: 10.1016/j.placenta.2005.11.008

47. Mjosberg J, Berg G, Jenmalm MC, Ernerudh J. FOXP3+ regulatory T cells and $\mathrm{T}$ helper $1, \mathrm{~T}$ helper 2, and T helper 17 cells in human early pregnancy decidua. Biol Reprod. (2010) 82:698-705. doi: 10.1095/biolreprod.109.081208

48. Zenclussen AC, Gerlof K, Zenclussen ML, Sollwedel A, Bertoja AZ, Ritter $\mathrm{T}$, et al. Abnormal T-cell reactivity against paternal antigens in spontaneous abortion: adoptive transfer of pregnancy-induced CD4+CD25+ $\mathrm{T}$ regulatory cells prevents fetal rejection in a murine abortion model. Am J Pathol. (2005) 166:811-22. doi: 10.1016/S0002-9440(10)62302-4

49. Shima T, Sasaki Y, Itoh M, Nakashima A, Ishii N, Sugamura K, et al. Regulatory $\mathrm{T}$ cells are necessary for implantation and maintenance of early pregnancy but not late pregnancy in allogeneic mice. J Reprod Immunol. (2010) 85:121-9. doi: 10.1016/j.jri.2010.02.006

50. Rowe JH, Ertelt JM, Aguilera MN, Farrar MA, Way SS. Foxp3(+) regulatory $\mathrm{T}$ cell expansion required for sustaining pregnancy compromises host defense against prenatal bacterial pathogens. Cell Host Microbe. (2011) 10:54-64. doi: 10.1016/j.chom.2011.06.005

51. Keller CC, Eikmans M, van der Hoorn M-LP, Lashley LEELO. Recurrent miscarriages and the association with regulatory T cells; A systematic review. J Reprod Immunol. (2020) 139:103105. doi: 10.1016/j.jri.2020.103105

52. Sasaki Y, Darmochwal-Kolarz D, Suzuki D, Sakai M, Ito M, Shima T, et al. Proportion of peripheral blood and decidual CD4(+) CD25(bright) regulatory T cells in pre-eclampsia. Clin Exp Immunol. (2007) 149:139-45. doi: 10.1111/j.1365-2249.2007.03397.x

53. Han X, Ghaemi MS, Ando K, Peterson LS, Ganio EA, Tsai AS, et al. Differential Dynamics of the Maternal Immune System in Healthy Pregnancy and Preeclampsia. Front Immunol. (2019) 10:1305. doi: 10.3389/fimmu.2019.01305

54. Liu Y, Fan X, Wang R, Lu X, Dang YL, Wang H, et al. Singlecell RNA-seq reveals the diversity of trophoblast subtypes and patterns of differentiation in the human placenta. Cell Res. (2018) 28:819-32. doi: 10.1038/s41422-018-0066-y

55. Guerin LR, Prins JR, Robertson SA. Regulatory T-cells and immune tolerance in pregnancy: a new target for infertility treatment? Hum Reprod Update. (2009) 15:517-35. doi: 10.1093/humupd/dmp004
56. Rai R, Regan L. Recurrent miscarriage. Lancet. (2006) 368:601-11. doi: 10.1016/S0140-6736(06)69204-0

57. Whitley GS, Cartwright JE. Trophoblast-mediated spiral artery remodelling: a role for apoptosis. J Anat. (2009) 215:21-6. doi: 10.1111/j.1469-7580.2008.01039.x

58. Gershon RK, Kondo K. Cell interactions in the induction of tolerance: the role of thymic lymphocytes. Immunology. (1970) 18:723-37.

59. Green DR, Flood PM, Gershon RK. Immunoregulatory T-cell pathways. Annu Rev Immunol. (1983) 1:439-63. doi: 10.1146/annurev.iy.01.040183.002255

60. Sakaguchi S, Wing K, Miyara M. Regulatory T cells - a brief history and perspective. Eur J Immunol. (2007) 37(Suppl. 1):S116-23. doi: 10.1002/eji.200737593

61. Brunkow ME, Jeffery EW, Hjerrild KA, Paeper B, Clark LB, Yasayko SA, et al. Disruption of a new forkhead/winged-helix protein, scurfin, results in the fatal lymphoproliferative disorder of the scurfy mouse. Nat Genet. (2001) 27:68-73. doi: 10.1038/83784

62. Hori S, Nomura T, Sakaguchi S. Control of regulatory T cell development by the transcription factor Foxp3. Science. (2003) 299:1057-61. doi: 10.1126/science. 1079490

63. Apostolou I, Sarukhan A, Klein L, von Boehmer H. Origin of regulatory T cells with known specificity for antigen. Nat Immunol. (2002) 3:756-63. doi: $10.1038 /$ ni816

64. Chen W, Jin W, Hardegen N, Lei KJ, Li L, Marinos N, et al. Conversion of peripheral CD4+CD25- naive $\mathrm{T}$ cells to $\mathrm{CD} 4+\mathrm{CD} 25+$ regulatory $\mathrm{T}$ cells by TGF-beta induction of transcription factor Foxp3. J Exp Med. (2003) 198:1875-86. doi: 10.1084/jem.20030152

65. Shevach EM, Thornton AM. tTregs, pTregs, and iTregs: similarities and differences. Immunol Rev. (2014) 259:88-102. doi: 10.1111/imr.12160

66. Thornton AM, Korty PE, Tran DQ, Wohlfert EA, Murray PE, Belkaid Y, et al. Expression of Helios, an Ikaros transcription factor family member, differentiates thymic-derived from peripherally induced Foxp3+ T regulatory cells. J Immunol. (2010) 184:3433-41. doi: 10.4049/jimmunol.0904028

67. Yadav M, Louvet C, Davini D, Gardner JM, Martinez-Llordella M, BaileyBucktrout S, et al. Neuropilin-1 distinguishes natural and inducible regulatory $\mathrm{T}$ cells among regulatory $\mathrm{T}$ cell subsets in vivo. J Exp Med. (2012) 209:1713-22. doi: 10.1084/jem.20120822

68. Corbel C, Lemarchandel V, Thomas-Vaslin V, Pelus AS, Agboton C, Romeo PH. Neuropilin 1 and CD25 co-regulation during early murine thymic differentiation. Dev Comp Immunol. (2007) 31:1082-94. doi: 10.1016/j.dci.2007.01.009

69. Szurek E, Cebula A, Wojciech L, Pietrzak M, Rempala G, Kisielow P, et al. Differences in expression level of helios and neuropilin-1 do not distinguish thymus-derived from extrathymically-induced CD4+Foxp3+ regulatory T cells. PLoS ONE. (2015) 10:e0141161. doi: 10.1371/journal.pone. 0141161

70. Elkord E. Helios should not be cited as a marker of human thymus-derived tregs. commentary: Helios(+) and Helios(-) cells coexist within the natural FOXP3(+) T regulatory cell subset in humans. Front Immunol. (2016) 7:276. doi: 10.3389/fimmu.2016.00276

71. Kim HJ, Barnitz RA, Kreslavsky T, Brown FD, Moffett H, Lemieux ME, et al. Stable inhibitory activity of regulatory $\mathrm{T}$ cells requires the transcription factor Helios. Science. (2015) 350:334-9. doi: 10.1126/science.aad0616

72. Hansen W, Hutzler M, Abel S, Alter C, Stockmann C, Kliche S, et al. Neuropilin 1 deficiency on CD4+Foxp3+ regulatory $\mathrm{T}$ cells impairs mouse melanoma growth. J Exp Med. (2012) 209:2001-16. doi: 10.1084/jem.20111497

73. Milpied P, Renand A, Bruneau J, Mendes-da-Cruz DA, Jacquelin S, Asnafi V, et al. Neuropilin-1 is not a marker of human Foxp3+ Treg. Eur J Immunol. (2009) 39:1466-71. doi: 10.1002/eji.200839040

74. Zheng Y, Josefowicz S, Chaudhry A, Peng XP, Forbush K, Rudensky AY. Role of conserved non-coding DNA elements in the Foxp3 gene in regulatory T-cell fate. Nature. (2010) 463:808-12. doi: 10.1038/nature08750

75. Rudensky AY. Regulatory T cells and Foxp3. Immunol Rev. (2011) 241:260-8. doi: 10.1111/j.1600-065X.2011.01018.x

76. Wagner MI, Jost M, Spratte J, Schaier M, Mahnke K, Meuer S, et al. Differentiation of ICOS+ and ICOS- recent thymic emigrant regulatory $\mathrm{T}$ 
cells. (RTE T regs) during normal pregnancy, pre-eclampsia and HELLP syndrome. Clin Exp Immunol. (2016) 183:129-42. doi: 10.1111/cei.12693

77. Joller N, Kuchroo VK. Tim-3, Lag-3, and TIGIT. Curr Top Microbiol Immunol. (2017) 410:127-56. doi: 10.1007/82_2017_62

78. Jiang L, Tang C, Gong Y, Liu Y, Rao J, Chen S, et al. PD-1/PD-L1 regulates Treg differentiation in pregnancy-induced hypertension. Braz J Med Biol Res. (2018) 51:e7334. doi: 10.1590/1414-431x20187334

79. Xu YY, Wang SC, Li DJ, Du MR. Co-signaling molecules in maternal-fetal immunity. Trends Mol Med. (2017) 23:46-58. doi: 10.1016/j.molmed.2016.11.001

80. Miko E, Meggyes M, Doba K, Barakonyi A, Szereday L. Immune checkpoint molecules in reproductive immunology. Front Immunol. (2019) 10:846. doi: 10.3389/fimmu.2019.00846

81. Zhang YH, Sun HX. Immune checkpoint molecules in pregnancy: focus on regulatory $T$ cells. Eur J Immunol. (2020) 50:160-9. doi: 10.1002/eji.201948382

82. Sakaguchi S, Sakaguchi N, Asano M, Itoh M, Toda M. Immunologic selftolerance maintained by activated $\mathrm{T}$ cells expressing IL-2 receptor alphachains. (CD25). Breakdown of a single mechanism of self-tolerance causes various autoimmune diseases. J Immunol. (1995) 155:1151-64.

83. Liu W, Putnam AL, Xu-Yu Z, Szot GL, Lee MR, Zhu S, et al. CD127 expression inversely correlates with FoxP3 and suppressive function of human CD4+ T reg cells. J Exp Med. (2006) 203:1701-11. doi: 10.1084 /jem.20060772

84. Yu N, Li X, Song W, Li D, Yu D, Zeng X, et al. CD4(+)CD25. (+)CD127. (low/-) T cells: a more specific Treg population in human peripheral blood. Inflammation. (2012) 35:1773-80. doi: 10.1007/s10753-012-9496-8

85. Kosten IJ, Rustemeyer T. Generation, subsets and functions of inducible regulatory T cells. Antiinflamm Antiallergy Agents Med Chem. (2015) 13:139-53. doi: $10.2174 / 1871523013666141126100019$

86. Jorgensen N, Persson G, Hviid TVF. The tolerogenic function of regulatory t cells in pregnancy and cancer. Front Immunol. (2019) 10:911. doi: 10.3389/fimmu.2019.00911

87. Tsuda S, Nakashima A, Shima T, Saito S. New paradigm in the role of regulatory T cells during pregnancy. Front Immunol. (2019) 10:573. doi: 10.3389/fimmu.2019.00573

88. Mosser DM, Zhang X. Interleukin-10: new perspectives on an old cytokine. Immunol Rev. (2008) 226:205-18. doi: 10.1111/j.1600-065X.2008.00706.x

89. Thaxton JE, Sharma S. Interleukin-10: a multi-faceted agent of pregnancy. Am J Reprod Immunol. (2010) 63:482-91. doi: 10.1111/j.1600-0897.2010.00810.x

90. Busse M, Campe KJ, Nowak D, Schumacher A, Plenagl S, Langwisch S, et al. IL-10 producing B cells rescue mouse fetuses from inflammation-driven fetal death and are able to modulate T cell immune responses. Sci Rep. (2019) 9:9335. doi: 10.1038/s41598-019-45860-2

91. Svensson L, Arvola M, Sallstrom MA, Holmdahl R, Mattsson R. The Th2 cytokines IL-4 and IL-10 are not crucial for the completion of allogeneic pregnancy in mice. J Reprod Immunol. (2001) 51:3-7. doi: 10.1016/S0165-0378(01)00065-1

92. Murphy SP, Fast LD, Hanna NN, Sharma S. Uterine NK cells mediate inflammation-induced fetal demise in IL-10-null mice. J Immunol. (2005) 175:4084-90. doi: 10.4049/jimmunol.175.6.4084

93. Hennessy A, Pilmore HL, Simmons LA, Painter DM. A deficiency of placental IL-10 in preeclampsia. J Immunol. (1999) 163:3491-5.

94. Raghupathy R, Makhseed M, Azizieh F, Hassan N, Al-Azemi M, Al-Shamali E. Maternal Th1- and Th2-type reactivity to placental antigens in normal human pregnancy and unexplained recurrent spontaneous abortions. Cell Immunol. (1999) 196:122-30. doi: 10.1006/cimm.1999.1532

95. Plevyak M, Hanna N, Mayer S, Murphy S, Pinar H, Fast L, et al. Deficiency of decidual IL-10 in first trimester missed abortion: a lack of correlation with the decidual immune cell profile. Am J Reprod Immunol. (2002) 47:242-50. doi: 10.1034/j.1600-0897.2002.01060.x

96. Banerjee P, Ghosh S, Dutta M, Subramani E, Khalpada J, Roychoudhury $\mathrm{S}$, et al. Identification of key contributory factors responsible for vascular dysfunction in idiopathic recurrent spontaneous miscarriage. PLOS ONE. (2013) 8:e80940. doi: 10.1371/journal.pone.0080940

97. Wang LQ, Yan XT, Yan CF, Zhang XW, Hui LY, Xue M, et al. Women with recurrent miscarriage have decreased expression of 25-hydroxyvitamin
D3-1alpha-hydroxylase by the fetal-maternal interface. PLoS ONE. (2016) 11:e0165589. doi: 10.1371/journal.pone.0165589

98. Azizieh FY, Raghupathy R. IL-10 and pregnancy complications. Clin Exp Obstet Gynecol. (2017) 44:252-8. doi: 10.12891/ceog3456.2017

99. Moreau P, Adrian-Cabestre F, Menier C, Guiard V, Gourand L, Dausset J, et al. IL-10 selectively induces HLA-G expression in human trophoblasts and monocytes. Int Immunol. (1999) 11:803-11. doi: 10.1093/intimm/11.5.803

100. Steinbrink K, Wolfl M, Jonuleit H, Knop J, Enk AH. Induction of tolerance by IL-10-treated dendritic cells. J Immunol. (1997) 159:4772-80.

101. Ristich V, Liang S, Zhang W, Wu J, Horuzsko A. Tolerization of dendritic cells by HLA-G. Eur J Immunol. (2005) 35:1133-42. doi: 10.1002/eji.200425741

102. Manavalan JS, Rossi PC, Vlad G, Piazza F, Yarilina A, Cortesini R, et al. High expression of ILT3 and ILT4 is a general feature of tolerogenic dendritic cells. Transpl Immunol. (2003) 11:245-58. doi: 10.1016/S0966-3274(03)00058-3

103. Gregori S, Magnani CF, Roncarolo MG. Role of human leukocyte antigen-G in the induction of adaptive type 1 regulatory T cells. Hum Immunol. (2009) 70:966-9. doi: 10.1016/j.humimm.2009.07.022

104. Comi M, Amodio G, Gregori S. Interleukin-10-producing DC-10 is a unique tool to promote tolerance via antigen-specific $\mathrm{T}$ regulatory type 1 cells. Front Immunol. (2018) 9:682. doi: 10.3389/fimmu.2018.00682

105. Gregori S, Tomasoni D, Pacciani V, Scirpoli M, Battaglia M, Magnani $\mathrm{CF}$, et al. Differentiation of type $1 \mathrm{~T}$ regulatory cells. (Tr1) by tolerogenic DC-10 requires the IL-10-dependent ILT4/HLA-G pathway. Blood. (2010) 116:935-44. doi: 10.1182/blood-2009-07-234872

106. Ip WKE, Hoshi N, Shouval DS, Snapper S, Medzhitov R. Anti-inflammatory effect of IL-10 mediated by metabolic reprogramming of macrophages. Science. (2017) 356:513-9. doi: 10.1126/science.aal3535

107. O'Farrell AM, Liu Y, Moore KW, Mui AL. IL-10 inhibits macrophage activation and proliferation by distinct signaling mechanisms: evidence for Stat3-dependent and -independent pathways. EMBO J. (1998) 17:1006-18. doi: 10.1093/emboj/17.4.1006

108. Groux H, Bigler M, de Vries JE, Roncarolo MG. Interleukin-10 induces a long-term antigen-specific anergic state in human CD4+ T cells. J Exp Med. (1996) 184:19-29. doi: 10.1084/jem.184.1.19

109. Levings MK, Sangregorio R, Galbiati F, Squadrone S, de Waal Malefyt $\mathrm{R}$, Roncarolo MG. IFN-alpha and IL-10 induce the differentiation of human type $1 \mathrm{~T}$ regulatory cells. J Immunol. (2001) 166:5530-9. doi: 10.4049/jimmunol.166.9.5530

110. Levings MK, Gregori S, Tresoldi E, Cazzaniga S, Bonini C, Roncarolo MG. Differentiation of $\operatorname{Tr} 1$ cells by immature dendritic cells requires IL-10 but not CD25+CD4+ Tr cells. Blood. (2005) 105:1162-9. doi: 10.1182/blood-2004-03-1211

111. Suzuki T, Hiromatsu K, Ando Y, Okamoto T, Tomoda Y, Yoshikai Y. Regulatory role of gamma delta $\mathrm{T}$ cells in uterine intraepithelial lymphocytes in maternal antifetal immune response. J Immunol. (1995) 154:4476-84.

112. Groux H, O'Garra A, Bigler M, Rouleau M, Antonenko S, de Vries JE, et al. A CD4+ T-cell subset inhibits antigen-specific T-cell responses and prevents colitis. Nature. (1997) 389:737-42. doi: 10.1038/39614

113. Inobe J, Slavin AJ, Komagata Y, Chen Y, Liu L, Weiner HL. IL-4 is a differentiation factor for transforming growth factor-beta secreting Th 3 cells and oral administration of IL-4 enhances oral tolerance in experimental allergic encephalomyelitis. Eur J Immunol. (1998) 28:2780-90.

114. Weiner HL. The mucosal milieu creates tolerogenic dendritic cells and $\mathrm{T}(\mathrm{R}) 1$ and $\mathrm{T}(\mathrm{H}) 3$ regulatory cells. Nat Immunol. (2001) 2:671-2. doi: 10.1038/90604

115. Nagaeva O, Jonsson L, Mincheva-Nilsson L. Dominant IL-10 and TGFbeta mRNA expression in gammadeltaT cells of human early pregnancy decidua suggests immunoregulatory potential. Am J Reprod Immunol. (2002) 48:9-17. doi: 10.1034/j.1600-0897.2002.01131.x

116. Cobbold SP, Adams E, Nolan KF, Regateiro FS, Waldmann H. Connecting the mechanisms of T-cell regulation: dendritic cells as the missing link. Immunol Rev. (2010) 236:203-18. doi: 10.1111/j.1600-065X.2010.00913.x

117. Sanjabi S, Oh SA, Li MO. Regulation of the immune response by TGF-beta: from conception to autoimmunity and infection. Cold Spring Harb Perspect Biol. (2017) 9:a022236. doi: 10.1101/cshperspect.a022236

118. Pollheimer J, Vondra S, Baltayeva J, Beristain AG, Knofler M. Regulation of placental extravillous trophoblasts by the maternal uterine environment. Front Immunol. (2018) 9:2597. doi: 10.3389/fimmu.2018.02597 
119. Salvany-Celades M, van der Zwan A, Benner M, Setrajcic-Dragos V, Bougleux Gomes HA, Iyer V, et al. Three types of functional regulatory $\mathrm{T}$ cells control $\mathrm{T}$ cell responses at the human maternal-fetal interface. Cell Rep. (2019) 27:2537-47 e2535. doi: 10.1016/j.celrep.2019.04.109

120. Zhang J, Dunk CE, Shynlova O, Caniggia I, Lye SJ. TGFb1 suppresses the activation of distinct $\mathrm{dNK}$ subpopulations in preeclampsia. EBioMedicine. (2019) 39:531-9. doi: 10.1016/j.ebiom.2018.12.015

121. Lash GE, Otun HA, Innes BA, Bulmer JN, Searle RF, Robson SC. Inhibition of trophoblast cell invasion by TGFB1, 2, and 3 is associated with a decrease in active proteases. Biol Reprod. (2005) 73:374-81. doi: 10.1095/biolreprod.105.040337

122. Lafontaine L, Chaudhry P, Lafleur MJ, Van Themsche C, Soares MJ, Asselin E. Transforming growth factor Beta regulates proliferation and invasion of rat placental cell lines. Biol Reprod. (2011) 84:553-9. doi: 10.1095/biolreprod.110.086348

123. Singh M, Orazulike NC, Ashmore J, Konje JC. Changes in maternal serum transforming growth factor beta-1 during pregnancy: a cross-sectional study. Biomed Res Int. (2013) 2013:318464. doi: 10.1155/2013/318464

124. Xie J, Cao Y. Expression of TGF-betal and miR-99a in serum of patients with early spontaneous abortion and correlation with hormone levels during pregnancy. Exp Ther Med. (2019) 17:4593-7. doi: 10.3892/etm.2019.7477

125. Qiu T, Teng Y, Wang Y, Xu L. Adoptive transfer of transforming growth factor-?1-induced CD4+CD25+ regulatory $\mathrm{T}$ cells prevents immune response-mediated spontaneous abortion. Reprod Fertil Dev. (2015) 28:1788-97. doi: 10.1071/RD14503

126. Delisle JS, Giroux M, Boucher G, Landry JR, Hardy MP, Lemieux $\mathrm{S}$, et al. The TGF-beta-Smad3 pathway inhibits CD28-dependent cell growth and proliferation of CD4 T cells. Genes Immun. (2013) 14:115-26. doi: 10.1038/gene.2012.63

127. Viel S, Marcais A, Guimaraes FS, Loftus R, Rabilloud J, Grau M, et al. TGFbeta inhibits the activation and functions of NK cells by repressing the mTOR pathway. Sci Signal. (2016) 9:ra19. doi: 10.1126/scisignal.aad1884

128. Gorelik L, Constant S, Flavell RA. Mechanism of transforming growth factor beta-induced inhibition of T helper type 1 differentiation. J Exp Med. (2002) 195:1499-505. doi: 10.1084/jem.20012076

129. Gorelik L, Flavell RA. Transforming growth factor-beta in T-cell biology. Nat Rev Immunol. (2002) 2:46-53. doi: 10.1038/nri704

130. Bogdan C, Nathan C. Modulation of macrophage function by transforming growth factor beta, interleukin-4, and interleukin-10. Ann N Y Acad Sci. (1993) 685:713-39. doi: 10.1111/j.1749-6632.1993.tb35934.x

131. Vodovotz Y, Bogdan C. Control of nitric oxide synthase expression by transforming growth factor-beta: implications for homeostasis. Prog Growth Factor Res. (1994) 5:341-51. doi: 10.1016/0955-2235(94)00004-5

132. Lee YJ, Han Y, Lu HT, Nguyen V, Qin H, Howe PH, et al. TGF-beta suppresses IFN-gamma induction of class II MHC gene expression by inhibiting class II transactivator messenger RNA expression. J Immunol. (1997) 158:2065-75.

133. Nandan D, Reiner NE. TGF-beta attenuates the class II transactivator and reveals an accessory pathway of IFN-gamma action. J Immunol. (1997) 158:1095-101.

134. Yamaguchi Y, Tsumura H, Miwa M, Inaba K. Contrasting effects of TGF-beta 1 and TNF-alpha on the development of dendritic cells from progenitors in mouse bone marrow. Stem Cells. (1997) 15:144-53. doi: 10.1002/stem.150144

135. Weiner HL. Induction and mechanism of action of transforming growth factor-beta-secreting Th3 regulatory cells. Immunol Rev. (2001) 182:207-14. doi: 10.1034/j.1600-065X.2001.1820117.x

136. Levings MK, Bacchetta R, Schulz U, Roncarolo MG. The role of IL-10 and TGF-beta in the differentiation and effector function of $\mathrm{T}$ regulatory cells. Int Arch Allergy Immunol. (2002) 129:263-76. doi: 10.1159/0000 67596

137. Fu S, Zhang N, Yopp AC, Chen D, Mao M, Chen D, et al. TGF-beta induces Foxp3 + T-regulatory cells from CD4 + CD25 - precursors. Am J Transplant. (2004) 4:1614-27. doi: 10.1111/j.1600-6143.2004.00566.x

138. Carrier Y, Yuan J, Kuchroo VK, Weiner HL. Th3 cells in peripheral tolerance. I. Induction of Foxp3-positive regulatory $\mathrm{T}$ cells by Th3 cells derived from TGF-beta T cell-transgenic mice. J Immunol. (2007) 178:179-85. doi: 10.4049/jimmunol.178.1.179

139. Feger U, Tolosa E, Huang YH, Waschbisch A, Biedermann T, Melms A, et al. HLA-G expression defines a novel regulatory T-cell subset present in human peripheral blood and sites of inflammation. Blood. (2007) 110:56877. doi: 10.1182/blood-2006-11-057125

140. Carosella ED, Gregori S, LeMaoult J. The tolerogenic interplay(s) among HLA-G, myeloid APCs, and regulatory cells. Blood. (2011) 118:6499-505. doi: 10.1182/blood-2011-07-370742

141. Amodio G, Mugione A, Sanchez AM, Vigano P, Candiani M, Somigliana $\mathrm{E}$, et al. HLA-G expressing DC-10 and CD4(+) T cells accumulate in human decidua during pregnancy. Hum Immunol. (2013) 74:406-11. doi: 10.1016/j.humimm.2012.11.031

142. HoWangYin KY, Loustau M, Wu J, Alegre E, Daouya M, Caumartin J, et al. Multimeric structures of HLA-G isoforms function through differential binding to LILRB receptors. Cell Mol Life Sci. (2012) 69:4041-9. doi: 10.1007/s00018-012-1069-3

143. Chen XY, Yan WH, Lin A, Xu HH, Zhang JG, Wang XX. The 14 bp deletion polymorphisms in HLA-G gene play an important role in the expression of soluble HLA-G in plasma. Tissue Antigens. (2008) 72:335-41. doi: 10.1111/j.1399-0039.2008.01107.x

144. Craenmehr MHC, Haasnoot GW, Drabbels JJM, Spruyt-Gerritse MJ, Cao M, van der Keur C, et al. Soluble HLA-G levels in seminal plasma are associated with HLA-G 3'UTR genotypes and haplotypes. HLA. (2019) 94:339-46. doi: $10.1111 / \tan .13628$

145. Hunt JS, Jadhav L, Chu W, Geraghty DE, Ober C. Soluble HLA-G circulates in maternal blood during pregnancy. Am J Obstet Gynecol. (2000) 183:682-8. doi: $10.1067 / \mathrm{mob} .2000 .106762$

146. Yie SM, Li LH, Li YM, Librach C. HLA-G protein concentrations in maternal serum and placental tissue are decreased in preeclampsia. Am J Obstet Gynecol. (2004) 191:525-9. doi: 10.1016/j.ajog.2004.01.033

147. Jassem RM, Shani WS, Loisel DA, Sharief M, Billstrand C, Ober C. HLA-G polymorphisms and soluble HLA-G protein levels in women with recurrent pregnancy loss from Basrah province in Iraq. Hum Immunol. (2012) 73:8117. doi: 10.1016/j.humimm.2012.05.009

148. Keskin F, Karatas A, Albayrak M, Biyik I, Erkan M, Demirin H, et al. Maternal serum soluble HLA-G levels in missed abortions. Medicina. (2013) 49:435-8. doi: 10.3390/medicina49100068

149. Gonzalez A, Rebmann V, LeMaoult J, Horn PA, Carosella ED, Alegre E. The immunosuppressive molecule HLA-G and its clinical implications. Crit Rev Clin Lab Sci. (2012) 49:63-84. doi: 10.3109/10408363.2012.677947

150. Li C, Houser BL, Nicotra ML, Strominger JL. HLA-G homodimerinduced cytokine secretion through HLA-G receptors on human decidual macrophages and natural killer cells. Proc Natl Acad Sci USA. (2009) 106:5767-72. doi: 10.1073/pnas.0901173106

151. Baudhuin J, Migraine J, Faivre V, Loumagne L, Lukaszewicz AC, Payen $\mathrm{D}$, et al. Exocytosis acts as a modulator of the ILT4-mediated inhibition of neutrophil functions. Proc Natl Acad Sci USA. (2013) 110:17957-62. doi: $10.1073 /$ pnas. 1221535110

152. Colonna M, Navarro F, Bellon T, Llano M, Garcia P, Samaridis J, et al. A common inhibitory receptor for major histocompatibility complex class I molecules on human lymphoid and myelomonocytic cells. J Exp Med. (1997) 186:1809-18. doi: 10.1084/jem.186.11.1809

153. Le Gal FA, Riteau B, Sedlik C, Khalil-Daher I, Menier C, Dausset J, et al. HLA-G-mediated inhibition of antigen-specific cytotoxic T lymphocytes. Int Immunol. (1999) 11:1351-6. doi: 10.1093/intimm/11.8.1351

154. Favier B, Lemaoult J, Lesport E, Carosella ED. ILT2/HLA-G interaction impairs NK-cell functions through the inhibition of the late but not the early events of the NK-cell activating synapse. FASEB J. (2010) 24:689-99. doi: 10.1096/fj.09-135194

155. Ajith A, Portik-Dobos V, Nguyen-Lefebvre AT, Callaway C, Horuzsko DD, Kapoor R, et al. HLA-G dimer targets Granzyme B pathway to prolong human renal allograft survival. FASEB J. (2019) 33:5220-36. doi: 10.1096/fj.201802017R

156. Rajagopalan S, Long EO. KIR2DL4. (CD158d): an activation receptor for HLA-G. Front Immunol. (2012) 3:258. doi: 10.3389/fimmu.2012.00258

157. Jonges LE, Albertsson P, van Vlierberghe RL, Ensink NG, Johansson BR, van de Velde CJ, et al. The phenotypic heterogeneity of human natural killer cells: presence of at least 48 different subsets in the peripheral blood. Scand J Immunol. (2001) 53:103-10. doi: 10.1046/j.1365-3083.2001.00838.x

158. Contini P, Ghio M, Poggi A, Filaci G, Indiveri F, Ferrone S, et al. Soluble HLA-A,-B,-C and -G molecules induce apoptosis in T and NK CD8+ cells 
and inhibit cytotoxic T cell activity through CD8 ligation. Eur J Immunol. (2003) 33:125-34. doi: 10.1002/immu.200390015

159. Lee CL, Guo Y, So KH, Vijayan M, Guo Y, Wong VH, et al. Soluble human leukocyte antigen G5 polarizes differentiation of macrophages toward a decidual macrophage-like phenotype. Hum Reprod. (2015) 30:2263-74. doi: 10.1093/humrep/dev196

160. LeMaoult J, Caumartin J, Daouya M, Favier B, Le Rond S, Gonzalez A, et al. Immune regulation by pretenders: cell-to-cell transfers of HLA-G make effector T cells act as regulatory cells. Blood. (2007) 109:2040-8. doi: 10.1182/blood-2006-05-024547

161. Magnani CF, Alberigo G, Bacchetta R, Serafini G, Andreani M, Roncarolo MG, et al. Killing of myeloid APCs via HLA class I, CD2 and CD226 defines a novel mechanism of suppression by human Tr1 cells. Eur J Immunol. (2011) 41:1652-62. doi: 10.1002/eji.201041120

162. Weiner HL. Oral tolerance: immune mechanisms and treatment of autoimmune diseases. Immunol Today. (1997) 18:335-43. doi: 10.1016/S0167-5699(97)01053-0

163. Dimova T, Nagaeva O, Stenqvist AC, Hedlund M, Kjellberg L, Strand $\mathrm{M}$, et al. Maternal Foxp3 expressing CD4+ CD25+ and CD4+ CD25regulatory T-cell populations are enriched in human early normal pregnancy decidua: a phenotypic study of paired decidual and peripheral blood samples. Am J Reprod Immunol. (2011) 66(Suppl. 1):44-56. doi: 10.1111/j.1600-0897.2011.01046.x

164. Shao L, Jacobs AR, Johnson VV, Mayer L. Activation of CD8+ regulatory T cells by human placental trophoblasts. J Immunol. (2005) 174:7539-47. doi: 10.4049/jimmunol.174.12.7539

165. Niedbala W, Cai B, Liu H, Pitman N, Chang L, Liew FY. Nitric oxide induces $\mathrm{CD} 4+\mathrm{CD} 25+$ Foxp3 regulatory $\mathrm{T}$ cells from $\mathrm{CD} 4+\mathrm{CD} 25 \mathrm{~T}$ cells via p53, IL-2, and OX40. Proc Natl Acad Sci USA. (2007) 104:15478-83. doi: $10.1073 /$ pnas. 0703725104

166. Niedbala W, Besnard AG, Jiang HR, Alves-Filho JC, Fukada SY, Nascimento $\mathrm{D}$, et al. Nitric oxide-induced regulatory $\mathrm{T}$ cells inhibit Th17 but not Th1 cell differentiation and function. J Immunol. (2013) 191:164-70. doi: $10.4049 /$ jimmunol.1202580

167. Hua F, Kang N, Gao YA, Cui LX, Ba DN, He W. Potential regulatory role of in vitro-expanded Vdeltal $\mathrm{T}$ cells from human peripheral blood. Immunol Res. (2013) 56:172-80. doi: 10.1007/s12026-013-8390-2

168. Terzieva A, Dimitrova V, Djerov L, Dimitrova P, Zapryanova S, Hristova I, et al. Early pregnancy human decidua is enriched with activated, fully differentiated and pro-inflammatory gamma/delta T cells with diverse TCR repertoires. Int J Mol Sci. (2019) 20:687. doi: 10.3390/ijms20030687

169. Huang YH, Zozulya AL, Weidenfeller C, Schwab N, Wiendl H. T cell suppression by naturally occurring HLA-G-expressing regulatory $\mathrm{CD} 4+\mathrm{T}$ cells is IL-10-dependent and reversible. J Leukoc Biol. (2009) 86:273-81. doi: $10.1189 / \mathrm{jlb} .1008649$

170. Pankratz S, Bittner S, Herrmann AM, Schuhmann MK, Ruck T, Meuth $\mathrm{SG}$, et al. Human CD4+ HLA-G+ regulatory $\mathrm{T}$ cells are potent suppressors of graft-versus-host disease in vivo. FASEB J. (2014) 28:3435-45. doi: 10.1096/fj.14-251074

171. Pankratz S, Ruck T, Meuth SG, Wiendl H. CD4(+)HLA-G(+) regulatory T cells: molecular signature and pathophysiological relevance. Hum Immunol. (2016) 77:727-33. doi: 10.1016/j.humimm.2016.01.016

172. Huang YH, Zozulya AL, Weidenfeller C, Metz I, Buck D, Toyka KV, et al. Specific central nervous system recruitment of HLA-G(+) regulatory T cells in multiple sclerosis. Ann Neurol. (2009) 66:171-83. doi: 10.1002/ana.21705

173. Hsu P, Santner-Nanan B, Joung S, Peek MJ, Nanan R. Expansion of CD4(+) HLA-G(+) T Cell in human pregnancy is impaired in pre-eclampsia. Am J Reprod Immunol. (2014) 71:217-28. doi: 10.1111/aji.12195

174. Passerini L, Di Nunzio S, Gregori S, Gambineri E, Cecconi M, Seidel MG, et al. Functional type 1 regulatory $\mathrm{T}$ cells develop regardless of FOXP3 mutations in patients with IPEX syndrome. Eur J Immunol. (2011) 41:112031. doi: 10.1002/eji.201040909

175. Akbari O, DeKruyff RH, Umetsu DT. Pulmonary dendritic cells producing IL-10 mediate tolerance induced by respiratory exposure to antigen. Nat Immunol. (2001) 2:725-31. doi: 10.1038/90667

176. Gagliani N, Magnani CF, Huber S, Gianolini ME, Pala M, Licona-Limon P, et al. Coexpression of CD49b and LAG-3 identifies human and mouse T regulatory type 1 cells. Nat Med. (2013) 19:739-46. doi: 10.1038/nm.3179
177. White AM, Wraith DC. Tr1-like T cells - an enigmatic regulatory T cell lineage. Front Immunol. (2016) 7:355. doi: 10.3389/fimmu.2016.00355

178. Akdis M, Verhagen J, Taylor A, Karamloo F, Karagiannidis C, Crameri R, et al. Immune responses in healthy and allergic individuals are characterized by a fine balance between allergen-specific T regulatory 1 and $\mathrm{T}$ helper 2 cells. J Exp Med. (2004) 199:1567-75. doi: 10.1084/jem.20032058

179. Haringer B, Lozza L, Steckel B, Geginat J. Identification and characterization of IL-10/IFN-gamma-producing effector-like $\mathrm{T}$ cells with regulatory function in human blood. J Exp Med. (2009) 206:1009-17. doi: $10.1084 /$ jem. 20082238

180. Schuler PJ, Saze Z, Hong CS, Muller L, Gillespie DG, Cheng D, et al. Human $\mathrm{CD} 4+\mathrm{CD} 39+$ regulatory $\mathrm{T}$ cells produce adenosine upon co-expression of surface CD73 or contact with CD73+ exosomes or CD73+ cells. Clin Exp Immunol. (2014) 177:531-43. doi: 10.1111/cei.12354

181. Niedzielska M, Israelsson E, Angermann B, Sidders BS, Clausen M, Catley $M$, et al. Differential gene expression in human tissue resident regulatory $\mathrm{T}$ cells from lung, colon, and blood. Oncotarget. (2018) 9:36166-84. doi: 10.18632 /oncotarget. 26322

182. Weiner HL, da Cunha AP, Quintana F, Wu H. Oral tolerance. Immunol Rev. (2011) 241:241-59. doi: 10.1111/j.1600-065X.2011.01017.x

183. Elkord E, Abd Al Samid M, Chaudhary B. Helios, and not FoxP3, is the marker of activated Tregs expressing GARP/LAP. Oncotarget. (2015) 6:20026-36. doi: 10.18632/oncotarget.4771

184. Bacchetta R, Sartirana C, Levings MK, Bordignon C, Narula S, Roncarolo MG. Growth and expansion of human $\mathrm{T}$ regulatory type 1 cells are independent from TCR activation but require exogenous cytokines. Eur J Immunol. (2002) 32:2237-45. doi: 10.1002/1521-4141(200208)32:8<2237::AID-IMMU2237>3.0.CO;2-2

185. Wahl SM, Swisher J, McCartney-Francis N, Chen WJ. TGF-beta: the perpetrator of immune suppression by regulatory $\mathrm{T}$ cells and suicidal $\mathrm{T}$ cells. J Leukoc Biol. (2004) 76:15-24. doi: 10.1189/jlb.1103539

186. Koelman CA, Coumans ABC, Nijman HW, Doxiadis IIN, Dekker GA, Claas FHJ. Correlation between oral sex and a low incidence of preeclampsia: a role for soluble HLA in seminal fluid? J Reprod Immunol. (2000) 46:155-66. doi: $10.1016 / \mathrm{S} 0165-0378(99) 00062-5$

187. Clark DA. Oral tolerance and the materno-fetal relationship. J Reprod Immunol. (2019) 134-135, 36-39. doi: 10.1016/j.jri.2019.07.003

188. Meuleman T, Baden N, Haasnoot GW, Wagner MM, Dekkers OM, le Cessie S, et al. Oral sex is associated with reduced incidence of recurrent miscarriage. J Reprod Immunol. (2019) 133:1-6. doi: $10.1016 /$ j.jri.2019.03.005

189. Liu Y, Lan Q, Lu L, Chen M, Xia Z, Ma J, et al. Phenotypic and functional characteristic of a newly identified CD8+ Foxp3- CD103+ regulatory T cells. J Mol Cell Biol. (2014) 6:81-92. doi: 10.1093/jmcb/ mjt026

190. Seligman SP, Buyon JP, Clancy RM, Young BK, Abramson SB. The role of nitric oxide in the pathogenesis of preeclampsia. Am J Obstet Gynecol. (1994) 171:944-8. doi: 10.1016/S0002-9378(94)70064-8

191. Nobunaga T, Tokugawa Y, Hashimoto K, Kimura T, Matsuzaki N, Nitta $\mathrm{Y}$, et al. Plasma nitric oxide levels in pregnant patients with preeclampsia and essential hypertension. Gynecol Obstet Invest. (1996) 41:189-93. doi: $10.1159 / 000292266$

192. Silver RK, Kupferminc MJ, Russell TL, Adler L, Mullen TA, Caplan MS. Evaluation of nitric oxide as a mediator of severe preeclampsia. Am J Obstetr Gynecol. (1996) 175:1013-7. doi: 10.1016/S0002-9378(96) 80044-5

193. Choi JW, Im MW, Pai SH. Nitric oxide production increases during normal pregnancy and decreases in preeclampsia. Ann Clin Lab Sci. (2002) 32:25763.

194. Yu X, Harden K, Gonzalez LC, Francesco M, Chiang E, Irving B, et al. The surface protein TIGIT suppresses $\mathrm{T}$ cell activation by promoting the generation of mature immunoregulatory dendritic cells. Nat Immunol. (2009) 10:48-57. doi: 10.1038/ni.1674

195. Joller N, Lozano E, Burkett PR, Patel B, Xiao S, Zhu C, et al. Treg cells expressing the coinhibitory molecule TIGIT selectively inhibit proinflammatory Th1 and Th17 cell responses. Immunity. (2014) 40:569-81. doi: 10.1016/j.immuni.2014. 02.012 
196. Fan DX, Duan J, Li MQ, Xu B, Li DJ, Jin LP. The decidual gammadelta $\mathrm{T}$ cells up-regulate the biological functions of trophoblasts via IL10 secretion in early human pregnancy. Clin Immunol. (2011) 141:284-92. doi: 10.1016/j.clim.2011.07.008

197. Peng G, Wang HY, Peng W, Kiniwa Y, Seo KH, Wang RF. Tumor-infiltrating gammadelta $\mathrm{T}$ cells suppress $\mathrm{T}$ and dendritic cell function via mechanisms controlled by a unique toll-like receptor signaling pathway. Immunity. (2007) 27:334-48. doi: 10.1016/j.immuni.2007.05.020

198. Psarra K, Kapsimali V, Tarassi K, Dendrinos S, Athanasiadis T, Botsis $\mathrm{D}$, et al. TCRgammadelta $+\mathrm{T}$ lymphocytes in unexplained recurrent spontaneous abortions. Am J Reprod Immunol. (2001) 45:6-11. doi: 10.1111/j.8755-8920.2001.450102.x

199. Shima T, Inada K, Nakashima A, Ushijima A, Ito M, Yoshino O, et al. Paternal antigen-specific proliferating regulatory $\mathrm{T}$ cells are increased in uterine-draining lymph nodes just before implantation and in pregnant uterus just after implantation by seminal plasma-priming in allogeneic mouse pregnancy. J Reprod Immunol. (2015) 108:72-82. doi: 10.1016/j.jri.2015.02.005

200. Lansac J, Royere D. Follow-up studies of children born after frozen sperm donation. Human Reproduction Update. (2001) 7:33-7. doi: 10.1093/humupd/7.1.33

201. Robertson SA, Green ES, Care AS, Moldenhauer LM, Prins JR, Hull ML, et al. Therapeutic potential of regulatory $\mathrm{T}$ cells in preeclampsia-opportunities and challenges. Front Immunol. (2019) 10:478. doi: 10.3389/fimmu.2019.00478

202. Huhn O, Ivarsson MA, Gardner L, Hollinshead M, Stinchcombe JC, Chen $\mathrm{P}$, et al. Distinctive phenotypes and functions of innate lymphoid cells in human decidua during early pregnancy. Nat Commun. (2020) 11:381. doi: 10.1038/s41467-01 9-14123-Z

203. Peterson LS, Stelzer IA, Tsai AS, Ghaemi MS, Han X, Ando K, et al. Multiomic immune clockworks of pregnancy. Semin Immunopathol. (2020). doi: 10.1007/s00281-01900772-1

Conflict of Interest: The authors declare that the research was conducted in the absence of any commercial or financial relationships that could be construed as a potential conflict of interest.

Copyright (c) 2020 Krop, Heidt, Claas and Eikmans. This is an open-access article distributed under the terms of the Creative Commons Attribution License (CC BY).

The use, distribution or reproduction in other forums is permitted, provided the original author(s) and the copyright owner(s) are credited and that the original publication in this journal is cited, in accordance with accepted academic practice. No use, distribution or reproduction is permitted which does not comply with these terms. 